\title{
Design, Engineering and Discovery of Novel $\alpha$-Helical and $\beta$-Boomerang Antimicrobial Peptides against Drug Resistant Bacteria
}

\author{
Surajit Bhattacharjya ${ }^{1, *}$ and Suzana K. Straus ${ }^{2, *(1)}$ \\ 1 School of Biological Sciences, 60 Nanyang Drive, Nanyang Technological University, \\ Singapore 637551, Singapore \\ 2 Department of Chemistry, University of British Columbia, 2036 Main Mall, Vancouver, BC V6T 1Z1, Canada \\ * Correspondence: Surajit@ntu.edu.sg (S.B.); sstraus@chem.ubc.ca (S.K.S.)
}

Received: 27 July 2020; Accepted: 7 August 2020; Published: 11 August 2020

\begin{abstract}
In an era where the pipeline of new antibiotic development is drying up, the continuous rise of multi-drug resistant (MDR) and extensively drug resistant (XDR) bacteria are genuine threats to human health. Although antimicrobial peptides (AMPs) may serve as promising leads against drug resistant bacteria, only a few AMPs are in advanced clinical trials. The limitations of AMPs, namely their low in vivo activity, toxicity, and poor bioavailability, need to be addressed. Here, we review engineering of frog derived short $\alpha$-helical AMPs (aurein, temporins) and lipopolysaccharide (LPS) binding designed $\beta$-boomerang AMPs for further development. The discovery of novel cell selective AMPs from the human proprotein convertase furin is also discussed.
\end{abstract}

Keywords: multi-drug resistant (MDR) bacteria; extensively drug resistant (XDR) bacteria; antimicrobial peptides (AMPs); lipopolysaccharide (LPS) binding; $\alpha$-helical and $\beta$-boomerang AMPs

\section{Introduction}

Antimicrobial peptides (AMPs) protect organisms from all kingdoms of life against infections. The innate immune system of humans and other mammals serves as a first line of defense against a wide range of invading pathogens that may encompass bacteria, fungi, viruses, and parasites [1-4]. AMPs are an integral component of the host defense innate immunity. The defensive role of AMPs against infections in humans has been underscored by the observations that down regulation of the production of AMPs e.g., LL37, defensins, yielded increased susceptibility of bacterial diseases [5-7]. Apart from their potential direct in vivo killing of pathogens, multiple other biological functions are linked to AMPs, which are consequently also termed Host Defense Peptides (HDPs) [3]. AMPs can display a range of immunomodulatory activities $[2,8,9]$, including anti-inflammatory, pro-inflammatory, adaptive immunity, chemotaxis, and endotoxin neutralization. AMPs can mediate immunomodulation, and have, although indirectly, been connected to the elimination of invading pathogens. Some AMPs are known to promote wound-healing, angiogenesis, and also to exert lethal effects against cancer cells [3,10-12]. Increasingly, the antibiofilm activity of AMPs has been characterized [13-15]. AMPs have been shown to be active in the inhibition, dispersal, and eradication of bacterial biofilms. The synergistic property of AMPs with conventional antibiotics in killing both planktonic and biofilm bacteria has been demonstrated [16].

Given the diverse activity of AMPs, research in the last few decades has focused on characterizing AMPs and finding active sequences, with the major goal of developing AMPs as peptide-based alternatives to antibiotics $[17,18]$. The surge of drug resistant, multidrug resistant (MDR), and extremely drug resistant $(\mathrm{XDR})$ bacteria are a significant challenge to human health [19]. Novel antibiotics are 
urgently needed to treat infections that are caused by the ESKAPE (Enterococcus faecium, Staphylococcus aureus, Klebsiella pneumoniae, Acinetobacter baumannii, Pseudomonas aeruginosa, Enterobacter cloacae) group of pathogens. In 2019, the US centers for disease control and prevention (CDC) reported an estimated annual number of antibiotic-resistant infections of 2.8 million, resulting in 35,000 deaths [20]. Further, the CDC has highlighted carbapenem resistant Acinetobacter, Enterobacteriaceae, drug resistant $N$. gonorrhoeae as urgent threats. Drug resistant campylobacter, extended spectrum $\beta$-lactamase (ESBL) producing Enterobacteriaceae, multi-drug resistant P. aeruginosa, drug resistant Salmonella, vancomycin resistant Enterococcus (VRE) and methicillin resistant S. aureus (MRSA) belong to the serious threats category. The potential treatment options against drug resistant Gram negative bacteria are generally even more challenging than for Gram positive, due to the impermeable outer membrane LPS barrier found in Gram negative bacteria. Given the lack of available antibiotics, infections that are caused by extremely drug resistant (XDR) P. aeruginosa and K. pneumoniae must be treated with polymyxins, which are nephrotoxic and neurotoxic [21], with new delivery systems being developed to mitigate these unwanted effects [22].

The ability of AMPs to kill drug resistant bacteria and the relatively low occurrence of resistance development suggest that AMPs or AMP-based peptides have high potential for the treatment of antibiotic resistant bacteria. For example, Gram negative bacteria that are colistin resistant can be sensitive to AMPs: LL-37, cecropin A, and magainin 1 have demonstrated lethality against colistin resistant K. pneumoniae [23]. Gaining a mechanistic understanding of the plethora of activities of AMPs would be vital to fully comprehend structure-activity correlations. The mode of anti-bacterial activity of AMPs differs vastly from that of antibiotics which chiefly target intracellular macromolecules [24,25]. In many cases, both outer-LPS (in Gram negative) and inner bacterial membranes are permeabilized or disrupted upon binding to AMPs, leading to cell lysis. Indeed, a large proportion of AMPs have been shown to kill bacteria through this membranolytic process [1,4,26-28]. However, some AMPs can also target intra-cellular DNA or protein components, followed by a non-lytic cell killing process [29-31]. The acquisition of amphipathic secondary structure has been considered as the driving force of AMP bacterial plasma membrane binding. A net positive charge, under physiological conditions, establishes ionic interactions with the negatively charged bacterial membrane, whereas the hydrophobic residues facilitate insertion into the non-polar milieu of the membrane.

Using inner membrane mimics, several models e.g., barrel stave, toroidal pore, carpet/detergent-like were proposed describing how AMPs can disrupt integrity of bacterial plasma membrane [4,26-28]. The broad-spectrum activity and high effectiveness in bacterial cell killing by AMPs would also require potential destabilization of the outer components of bacterial membranes [32,33]. However, the outer peptidoglycan layer of Gram positive bacteria is less effective in preventing drug permeation. Indeed, antibiotics and AMPs can penetrate across peptidoglycan layers [34,35]. In contrast, the outer membrane of Gram negative bacteria serves as an efficient permeability barrier for antibiotics, host defence proteins, and peptides [36-40]. Outer membrane permeability is largely maintained by the highly organized structure of LPS in the outer leaflet [35,41,42]. The broad-spectrum activity of AMPs requires the permeabilization of both the outer and inner membrane of Gram negative bacteria. Atomic-resolution structures of potent AMPs in LPS micelles have revealed plausible disruption mechanisms of the outer membrane of Gram negative bacteria [43-49]. These investigations showed compact tertiary structures of AMPs and potential ionic and hydrophobic interactions with the lipid A domain of LPS [40,50-53].

A large number of studies have demonstrated that AMPs could be promising molecules for the treatment of drug resistant bacteria. However, to-date, very few AMPs are in the advanced stages of clinical trials $[17,18,25]$ and most are being developed by smaller pharmaceutical companies. Reasons for these limited applications of AMPs are linked to the high cost of synthesis, low in vivo stability, host toxicity, and limited bioavailability. Consequently, strategies need to be employed to overcome these limitations in order to further develop the next generation of AMPs. The cost of chemical synthesis of AMPs can be minimized by shortening the length of AMPs through engineering and designing [54]. Large scale recombinant production of AMPs is also a viable option that would 
significantly reduce the cost of peptides [55]. Proteolytic degradation is likely to be the major cause of the short in vivo half-life of AMPs. Several strategies have been exploited for the generation of AMPs that are stable against proteases: e.g., cyclization of AMPs [56] and the introduction of disulfide bonds and covalent bonds between sidechains [57-59]. Alternative approaches to minimize proteolytic cleavage include producing synthetic AMPs that incorporate D-amino acids [60], $\beta$-amino acids [61], and other non-natural amino acids [62]. The topic of improving in vivo stability has been extensively reviewed elsewhere $[4,63,64]$, and it will not be discussed further here. In terms of toxicity, some studies have shown that the introduction of D-amino acids or the rational optimization of amphipathicity can help in lowering host toxicity [60,65-67]. Furthermore, toxic AMPs were converted to non-toxic peptides by replacing hydrophobic residues with polar or Ala in the potential heptad repeat units $[68,69]$. Finally, the last shortcoming of AMPs that involves improving their bioavailability has only been addressed in a limited manner. Some studies have shown that enriching AMPs with $\mathrm{Arg} / \operatorname{Trp}$ residues results in peptides with increased bioavailability [70]. Alternatively, the conjugation of AMPs with different polymers [71,72] or encapsulation in pegylated micelles [60] has been proposed as a feasible option to increase bioavailability [64].

Creating designed broad spectrum AMPs with high therapeutic index and improved bioavailability are of significance toward the development of peptide antibiotics. In the next sections, we describe engineering short $\alpha$-helical AMPs, namely temporins and aurein, to yield an improved activity spectrum. We further discuss de novo designed $\beta$-boomerang AMPs that target the LPS outer membrane of Gram negative bacteria. Finally, human proteins or the proteome could be rich source of future AMPs. Hence, we present the discovery of non-hemolytic non-cytotoxic broad spectrum AMPs from the human protease furin.

\section{Engineering Temporins for Superior Activity}

Skin secretions of frogs are a rich source of a variety of AMPs, which differ in composition, length, structure, and activity profile [73-76]. Indeed, a considerable fraction of AMPs (i.e., 1019 sequences) in the Antimicrobial Peptide Database (APD) are from frog [77]. Temporins are a group of short AMPs, 10 to 14 amino acids, which were first identified from screening the c-DNA library from the skin of the European red frog Rana temporaria [78-80]. Currently, there are 130 peptides listed under the family of temporins, some of which are isolated from different species of frog [81,82]. The antimicrobial activity and conformations of all the members of the temporin family have not yet been characterized. A peculiar feature of temporins that makes them strikingly different from many other AMPs is their low cationicity and high content of non-polar residues. Notably, the primary structures of some of the peptides are devoid of any basic amino acid residues [81,82]. To date, temporin-1Ta (TA), temporin-1Tb (TB), and temporin-1Tl (TL) have been the most widely investigated for activity, structure, synergy, rational design, engineering and SAR studies [83-92]. Table 1 shows amino acid sequences of temporins, as well as the designed analogs discussed here.

Table 1. Designed antimicrobial peptides (AMPs) derived from the frog skin Temporins temporin-1Ta (TA), temporin-1 $\mathrm{Tb}(\mathrm{TB})$, and temporin-1Tl (TL).

\begin{tabular}{|c|c|c|}
\hline Name & Sequence & Net Charge \\
\hline Temporin A (TA) & FLPLIGRVLSGIL-NH ${ }_{2}$ & +2 \\
\hline Temporin B (TB) & LLPIVGNLLKSLL-NH & +2 \\
\hline Temporin L (TL) & FVQWFSKFLGRIL-NH ${ }_{2}$ & +3 \\
\hline TB_KKG6A & KKLLPIVANLLKSLL-NH $_{2}$ & +4 \\
\hline TB_L1FK & FLPIVGLLKSLLK-NH & +3 \\
\hline TB-YK & KKYLLPIVGNLLKSLL-NH ${ }_{2}$ & +3 \\
\hline TL (P3, D-P10) & FVPWFSKFLpRIL-NH ${ }_{2}$ & +2 \\
\hline TL analog 9 & FVPWFSKFlkRIL-NH ${ }_{2}$ & +4 \\
\hline TL analog 10 & FVPWFSKFIWRIL-NH ${ }_{2}$ & +3 \\
\hline TA- $\beta$-boomerang (FG21) & FLPLIGRVLSGILGWKRKRFG-NH ${ }_{2}$ & +6 \\
\hline TB- $\beta$-boomerang (LG21) & LLPIVGNLLKSLLGWKRKRFG-NH ${ }_{2}$ & +6 \\
\hline
\end{tabular}


TA and TB were found to be active against Gram positive bacteria, including clinical isolates, while being only weakly hemolytic [79]. In addition, TA and TB also displayed growth inhibition of viruses, protoza, and parasitic activity in in vitro assays [93-96]. In vitro wound healing activity of TA and TB has also been reported [97,98]. However, TA and TB are unbale to exert any lethal effect on Gram negative bacteria. In contrast, TL was observed to be active against both Gram positive and Gram negative bacteria [80]. TL also displayed antifungal activity and it was toxic to certain cancer cells $[99,100]$. Unfortunately, TL has a low therapeutic index due to its high hemolytic and cytotoxic activities [84]. The multi-functional nature and short sequences of TA, TB, and TL have made these peptides attractive templates for the development of antimicrobial therapeutics. Extensive mechanistic [88,101-104] and structural studies [90,105-107] of TA, TB, and TL (Figure 1) provided essential information in the design of analogs.
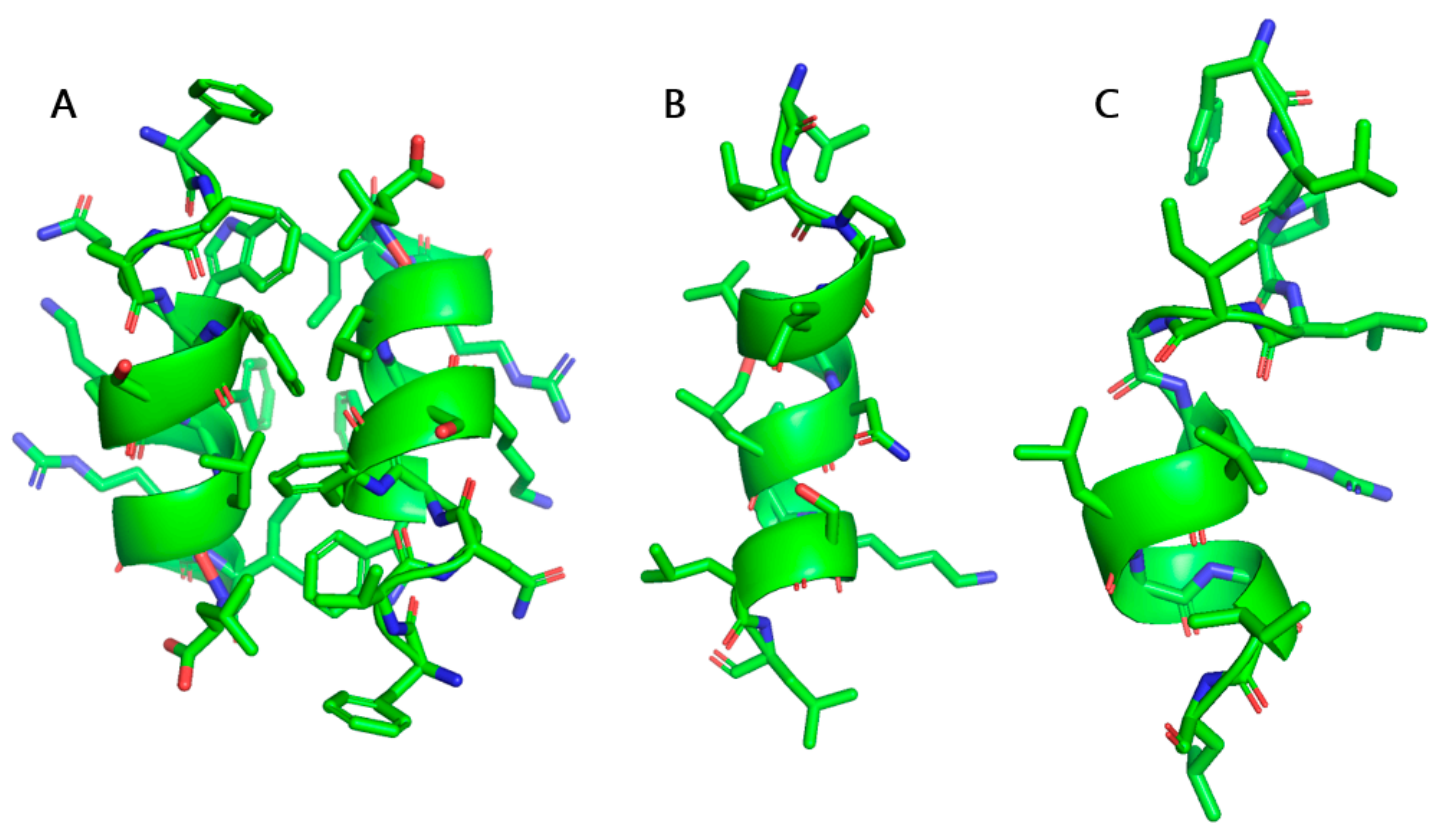

Figure 1. Structures of (A) the TL dimer; (B) TA; and, (C) TB in LPS. TL assumes an anti-parallel dimeric structure, stabilized by packing of aromatic and hydrophobic residues. The monomeric helical structures of TB and TA were obtained in the presence of TL peptide. The helical fold is represented by a ribbon. The figure was prepared using PyMOL molecular modelling software. The atomic coordinates of TL and TB were deposited in the BMRB data bank with accession numbers 21008 and 21005, respectively. The atomic coordinates of TA can be found in the Protein Data Bank with accession number 2MAA.

TB and TA gained more attention for the development of broad spectrum AMPs due to their low hemolytic activity. The analogs of TB were chiefly designed to yield broad spectrum activity by increasing cationicity and hydrophobicity. An analog of TB was developed, termed TB_KKG6A (Table 1), through Ala scanning replacement and the introduction of basic Lys residues at the N-terminus. TB_KKG6A showed activity against Gram negative strain S. typhimurium (minimum inhibitory concentration (MIC) $\sim 6 \mu \mathrm{M}$ ) and E. coli (MIC $\sim 3 \mu \mathrm{M}$ ) [105]. In LPS micelles, TB_KKG6A did not show any aggregation and formed a monomeric helix-kink-helix structure $[105,108]$. TB_L1FK (Table 1) is a computationally designed analog of TB that contains a replacement of Leu1 to Phe, the deletion of residue Asn at position 7, and an addition of Lys13 at the C-terminus. Studies comparing the antibacterial activity of TB_KKG6A and TB_L1KF $[109,110]$ showed that both analogs showed higher MIC values of 32 to $64 \mu \mathrm{M}$, against most of the Gram negative strains tested; however, TB_L1KF was found to have lower MIC values of 8 to $16 \mu \mathrm{M}$ against strains of Acinetobacter baumanii. Another analog of TB, TB-YK (Table 1), was examined in vivo with TA peptide [111]. TB-YK displayed 
moderate Gram negative activity and had synergetic in vivo activity with TA in a murine infection model. Extensive positional Ala scanning of TA yielded 13 analogs, which were characterized in detail in order to determine whether relationships between antibacterial activity, hemolytic activity, conformations, hydrophobicity, cationicity, and hydrophobic moment could be found [112]. Overall, most analogs were active against Gram positive bacteria, with some analogs being more potent than the parent peptide. However, the most active analogs were also more hemolytic and characterized by more helical content. Analogs of TL were designed by modulating helicity, hydrophobicity, charge, and amphipathicity: those that contained multiple Pro or D-Pro residues at positions of Gln3 and Gly10 (Table 1) showed sufficiently reduced hemolytic activity and also lower helicity [113]. However, the antibacterial activity of these Pro analogs were appreciably reduced when compared to the native TL. In further investigations, TL analog 9 and 10 (Table 1) were designed to be non-hemolytic, but displayed poor activity against clinical isolates and drug resistant bacteria [113]. Substitution of residue Phe to Leu at positions 5 and 8 yielded an analog that retained much of the antibacterial activity with lower cytotoxicity [114].

As the LPS outer membrane can inactivate TA and TB, as well as other AMPs, a different strategy was developed to design peptides with broad spectrum activity. A six-residue aromatic/cationic peptide, WKRKRF, termed $\beta$-boomerang motif, because, upon interaction with LPS, it folds into a compact 'boomerang' structure, was incorporated into the temporins [115]. It was hypothesized that the inclusion of this motif into AMPs might be effective in abolishing LPS outer membrane induced aggregations, consequently resulting in broad spectrum activity. The LPS binding $\beta$-boomerang motif was added to the C-terminus of TA to give FG21 (Table 1), of TB to give LG21 (Table 1), and of another helical peptide to give KG20. As expected, all three peptides demonstrated broad spectrum activity against Gram negative and Gram positive bacteria [116]. It is noteworthy that FG21 and LG21 retained much of their antibacterial activity in LB medium containing $150 \mathrm{mM}$ sodium chloride. In hemolysis assays, all three AMPs demonstrated limited lysis of human red blood cells (RBCs). Even at a concentration of $100 \mu \mathrm{M}$, the extent of hemolysis was found to be $8.5 \%, 9.9 \%$ and $2.4 \%$ for FG21, LG21 and KG20, respectively [116]. Furthermore, all three designed AMPs were bestowed with endotoxin neutralization potentially due to efficient interactions with LPS. Notably, LG21 demonstrated superior endotoxin neutralization activity in comparison to other two AMPs. An Ala substitution study further showed that residues Trp15, Arg19, and Phe20 were key to the broad spectrum antibacterial activity of the designed AMPs, which can be correlated with the absence of self-assembly in LPS micelles for the active analogues [116]. Furthermore, a separate study showed that individual replacement of other cationic residues namely Lys16, Arg17, Lys18 with Ala in the $\beta$-boomerang motif also yielded largely inactive analog peptides [117]. In contrast, Ala replacement of residues Asn7, Lys10 and Ser11 belonging to the TB part of LG21 did not cause any significant change in antibacterial activity. Therefore, these studies demonstrated that the $\beta$-boomerang motif is critical in determining broad spectrum antibacterial activity of the designed AMPs. The mechanism by which these AMPs kill bacterial cells has been shown to be the permeabilization of the outer membrane and inner membrane of Gram negative bacteria. Bacterial membrane permeabilization and dye entrapped liposome leakage assays performed on LG21 and the inactive versions LG21K16A, LG21R17A, LG21K18A, and LG21R19A revealed that LG21 displayed the largest effect toward bacterial membrane permeability followed by the other analogues in the following order: LG21 > LG21K16A > LG21R17A > LG21K18A > LG21R19A [117]. Similar observations were made in dye leakage assays using liposomes composed of 1-palmitoyl-2-oleoyl-phosphatidylcholine/phosphatidylglycerol (POPC:POPG) (3:1), which mimics the plasma membrane of bacteria. The atomic resolution structure of LG21 was determined in perdeuterated zwitterionic DPC micelles by NMR. In free solution LG21 assumes random conformations, whilst the micelle-bound state of LG21 is characterized by a well folded $\alpha$-helical structure encompassing residues Ile4 to Phe20 [117]. The three-dimensional (3-D) structure of LG21 revealed that the $\beta$-boomerang motif also folded in a helical conformation and sustained packing interactions with the helical region of the TB part (Figure 2). The topology of the 
helical structure of LG21 resembles a 'lollypop' or a 'drumstick': the bulky head of the lollypop is constituted by the $\beta$-boomerang motif, whereas the tail part of the 'lollypop' is maintained by the TB segment. The helical structure of LG21 displays a large hydrophobic surface that is mainly sustained by non-polar residues of TB and residue W15 of the $\beta$-boomerang motif. The polar surface of the helix is rather short, occupied by the sidechain of residues Asn7, Lys10, and Ser11. The $\beta$-boomerang segment of the LG21 helix contains potential cation- $\pi$ interactions in which the sidechains of the basic residues Arg19 and Lys16 interact with the aromatic sidechains of residues Trp14 and Phe20, respectively (Figure 2). Paramagnetic Relaxation Enhancement (PRE) NMR, using spin labelled lipid, indicated that the N-terminus of LG21 helix could be inserted into the hydrophobic core of micelles, whereas most of the residues in $\beta$-boomerang may reside at the micelle-water interface.

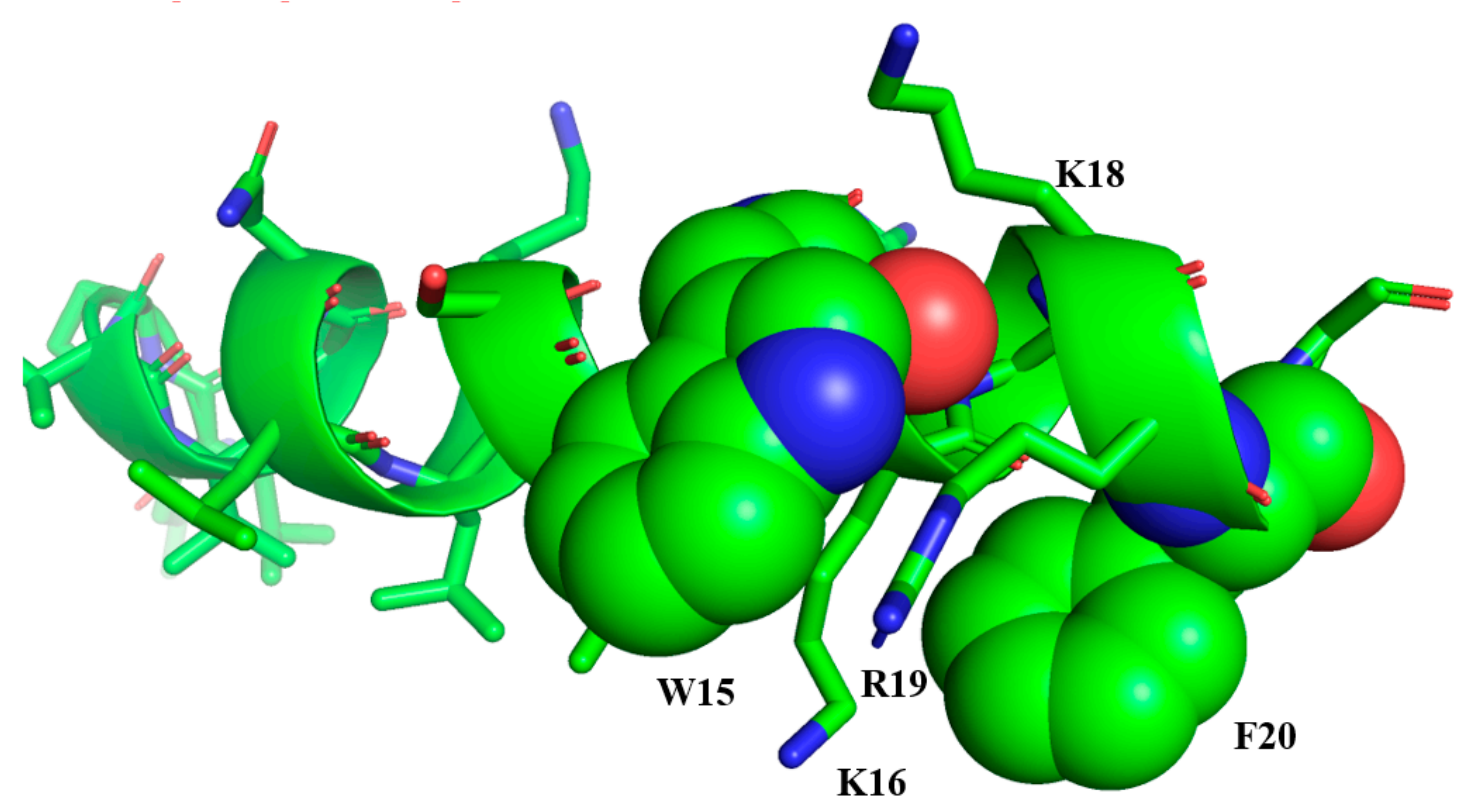

Figure 2. Structure of LG21 in micelles: the TB segment forms a well-defined $\alpha$-helical structure, while the $\beta$-boomerang motif packs with the helix to form a lollypop. The atomic coordinates of LG21 are available upon request from the authors.

\section{Engineering Aurein 2.2 for Superior Activity and Bioavailability}

Another rich source of frog skin AMPs is the aurein peptide family. Aurein peptides are cationic antimicrobial peptides that are secreted from the Australian southern bell frogs Litoria aurea and Litoria raniformis [118]. They are comprised of five families of aurein peptides, which include the short and active aurein peptides from family 1 to 3 , as well as longer and typically inactive family 4 and 5 peptides $[118,119]$. Aureins $1-3$ exhibit moderate broad spectrum activity against pathogens, with higher activity against Gram-positive bacteria versus Gram-negative bacteria [118]. In addition, aurein 1-3 peptides have anticancer activity. Indeed, some peptides, such as aurein 1.2,3.2, and 3.3, display their strongest activity against 30-50 different types of cancer [118]. Typically, aurein peptides range from 13 to 25 amino acid residues in length [120]. Specifically, aurein 2.2 and aurein 2.3 (Table 2) have a net charge of +2 and require an amidated C-terminus for activity [121]. They are active against Gram positive bacteria, such as S. aureus and S. epidermidis [121], with a MIC of 16-32 $\mu \mathrm{g} / \mathrm{mL}$ (or 9-18 $\mu \mathrm{M}$ ) against both. The N-terminus is required for activity, whereas truncation of three residues from the $\mathrm{C}$-terminus has no effect on its antimicrobial function $[122,123]$. The truncation of the $\mathrm{N}$-terminus makes aurein 2.2 immunomodulatory. Interestingly, a recent study comparing the structure and function of temporin $\mathrm{L}$ and aurein 2.5 [124] found that, although both AMPs adopt $\alpha$-helical structure, they disrupt membranes differently. The results presented for aurein 2.5 [124] mirror earlier studies [121,123], 
which showed that, as long as the residue at position 13 in aurein 2.2 is hydrophobic (i.e., L, I, V, A or F), the resulting peptides have similar structures and modes of action (i.e., as aurein 2.2, 2.3, and 2.5 do).

Table 2. Designed AMPs derived from the frog skin aurein 2.2.

\begin{tabular}{ccc}
\hline Name & Sequence & Net Charge \\
\hline aurein 2.2 & GLFDIVKKVVGALGSL-NH & +2 \\
aurein 2.3 & GLFDIVKKVVGAIGSL-NH & +2 \\
aurein 2.2- $\Delta 3$ & GLFDIVKKVVGAL-NH & +2 \\
peptide 73 & RLWDIVRRWVGWL-NH & +3 \\
peptide 77 & RLWDIVRRVWGWL-NH & +3 \\
\hline
\end{tabular}

The mechanism of action and structure of aurein 2.2 and aurein 2.3 have been extensively studied in recent years. Early studies showed the importance of studying bilayer perturbation in membrane models containing PG lipids, indicating that, as for most AMPs, electrostatic interactions are important in the lipid-peptide interaction [121]. Both aurein 2.2 and 2.3 adopt a highly $\alpha$-helical structure, resulting in a hydrophobic length of $\sim 24 \AA$. Given that a POPC:POPG bilayer has a thickness of $\sim 39 \AA$, these AMPs were found to disrupt POPC:POPG lipid membranes via toroidal pore formation, a very plausible mechanism given the mismatch [120]. In contrast, in a DMPC/DMPG (1:1) membrane model, the peptides work in a detergent like model $[120,122]$. This further highlights the importance of the hydrophobic thickness of the lipid bilayer and the membrane composition for the mechanism of action. These mechanisms of action are different from aurein 1.2, which functions using a carpet mechanism $[125,126]$. In a more recent study, Wenzel at al. [127] showed that aurein 2.2 forms ion selective pores, permitting the translocation of ions, such as potassium and magnesium. In addition, aurein 2.2 also causes membrane permeabilization, which disrupts the membrane potential and decreases the energy supply of the cells leading to cell death. Wenzel et al. also confirmed that truncation of aurein 2.2 by three amino acids at the C-terminus (denoted henceforth as aurein 2.2- $\Delta 3$, Table 2) had no impact on the mechanism of action when compared to the full-length natural peptide [127].

Arg and Trp residues were used to systematically replace residues in the parent peptide in order to design more active versions of aurein 2.2- $\Delta 3$. Previous work had shown that cationic residues such as Arg and Lys mediate the initial electrostatic interaction between HDPs and the bacterial cytoplasmic membrane [128,129], thereby resulting in more active AMPs. Trp residues preferably bind in the interfacial region of lipid membranes, thereby facilitating peptide-lipid interactions [128]. In addition, the use of both Arg and Trp amino acids allows for the formation of cation- $\pi$ interactions, which also serve to improve peptide-membrane interactions [129]. Finally, as mentioned earlier, enriching AMPs with Arg/Trp residues potentially results in peptides with increased bioavailability [70].

The ninety novel analogues were designed, such that the hydrophobic and basic amino acid residues of aurein 2.2- $\Delta 3$ were substituted with Trp and Arg, respectively, in order to increase favorable interactions. For most peptides, residues Asp4 and Ile 5 were kept unchanged and generally, aromatic (e.g., Phe3) and/or hydrophobic residues (e.g., Val9) were replaced by Trp and lysines (i.e., Lys7 and Lys8) were replaced by Arg (Table 2). Residue Asp4 was preserved in most analogues, as it has been previously suggested that it may play an important role in ion selectivity of aurein 2.2 [127]. Single to multiple (max. five individual Trp; three individual Arg; or a mixture of eight Trp and Arg residues) substitutions were made. The peptide array was generated using the SPOT-synthesis technique on cellulose membranes [71,130-132]. This approach had been previously utilized to generate large libraries of antibacterial, immunomodulatory, and antibiofilm peptides $[15,133,134]$. The SPOT synthesized $[131,132,135]$ peptides were tested for activity against $S$. aureus [71]. Peptides that contained one or more cation- $\pi$ interactions did not show dramatically improved activity (1-2x MIC of parent aurein 2.2- $\Delta 3$ ), with the exception of two peptides, which had MICs that were $8 \times$ better and in which two cation- $\pi$ interactions were present. 
In order to understand why the modifications introduced into the two peptides mentioned above (namely, peptides 73 and 77, Table 2) resulted in more active analogues, a detailed study of the structure and mechanism of action was conducted [136]. Peptides 73 and 77 were found to be more bactericidal, less $\alpha$-helical, and less likely to form clearly defined pores than aurein 2.2- $\Delta 3$. Indeed, the results obtained from $\mathrm{DiSC}_{3} 5$ and pyranine assays only showed modest membrane depolarization and ion leakage caused by peptides 73 and 77. Overall, the data presented by Raheem et al. [136] suggested that the more active analogues behaved more like cell-penetrating peptides (CPPs), i.e., more like indolicidin [129,137-139], catestatin [140], penetratin [141], or other CPPs [142-144], than aurein 2.2- $\Delta 3$. Indeed, these cell-penetrating peptides have sequence features in common with peptide 73 and peptide 77. Moreover, catestatin is also $\alpha$-helical for only part of the sequence [140]. As with other studies that involve AMP design, the higher antimicrobial activity that was associated with peptide 73 and peptide 77 was unfortunately also accompanied by higher hemolytic activity and cytotoxicity. This led us to explore bioconjugation and formulation strategies in order to mitigate these negative effects $[4,60,71]$. For an extensive review on these strategies, the reader is invited to consult [64] and references therein.

\section{De Novo Designed $\beta$-Boomerang LPS Binding Antimicrobial and Antiendotoxic Peptides}

A set of 12-residue long peptides were designed de novo for LPS binding and endotoxin neutralization. The primary structure of the first peptide in this series, YW12, is given in Table 3 . This peptide was expected to assume a $\beta$-sheet or $\beta$-hairpin like structure and form a complex with LPS, thereby structurally mimicking $\beta$-sheet outer membrane proteins [145]. Analogues (Table 3) were designed, as follows: the four residue cationic motif KRKR at the centre of the sequence would interact with the negatively charged phosphate groups of lipid A of LPS and, hence, stabilize peptide anchoring onto the LPS surface; at the same time, aromatic and hydrophobic residues at the N-and C-termini of YW12 would insert into the multi-acyl chain domains of LPS. Due to their high intrinsic propensity for adopting $\beta$-sheet structure, aromatic residues Tyr and Phe and $\beta$-branched residues Ile and Val were introduced to further ensure that the desired structure would be adopted. An ensemble of 3-D structures of YW12 was determined while bound to LPS micelles using tr-NOESY NMR. YW12 did not adopt a $\beta$-sheet or $\beta$-hairpin structure, as per the design. However, the peptide interacted with LPS and folded into a unique structure resembling a 'boomerang' (Figure 3). Observed NOEs established proximity ( $\leq 5 \AA$ ) between residues Trp4 and Met9, which appeared to be critical in shaping the boomerang fold of the YW12 peptide, thereby resulting in an amphipathic structure. As most of the residues were in $\beta$-strand conformations, the structure was termed a $\beta$-boomerang. A molecular model of LPS and YW12 revealed multiple ionic and hydrogen bond interactions between the KRKR motif with the lipid A domain of LPS. The N- and C-termini residues made facile packing with the non-polar acyl chains of LPS. YW12 peptide showed selective binding to anionic detergents and lipids and assumed $\beta$-conformations in a membrane milieu. However, the YW12 peptide showed only weak activity in the neutralization of endotoxin and lacked antibacterial activity.

Table 3. De Novo Designed $\beta$-boomerang AMPs.

\begin{tabular}{ccc}
\hline Name & Sequence & Net Charge \\
\hline YW12 & YVLWKRKRMIFI-OH & +4 \\
YI12WF ${ }^{1}$ & YVLWKRKRFIFI-NH $_{2}$ & +5 \\
YI12WY & YVLWKRKRYIFI-NH & +5 \\
YI12WW & YVLWKRKRWIFI-NH $_{2}$ & +5 \\
YI12FF & YVLFKRKRFIFI-NH & +5 \\
C4/C8-YI13C & C4/C8-YVLWKRKRKFCFI-NH & +6 \\
\hline
\end{tabular}

${ }^{1}$ Although the parent peptide was called YW12, the designed analog peptides were referred using their first and last amino acid residues. Also, amino acid residues replaced at positions 4 and 9 are included for ease of identification. 

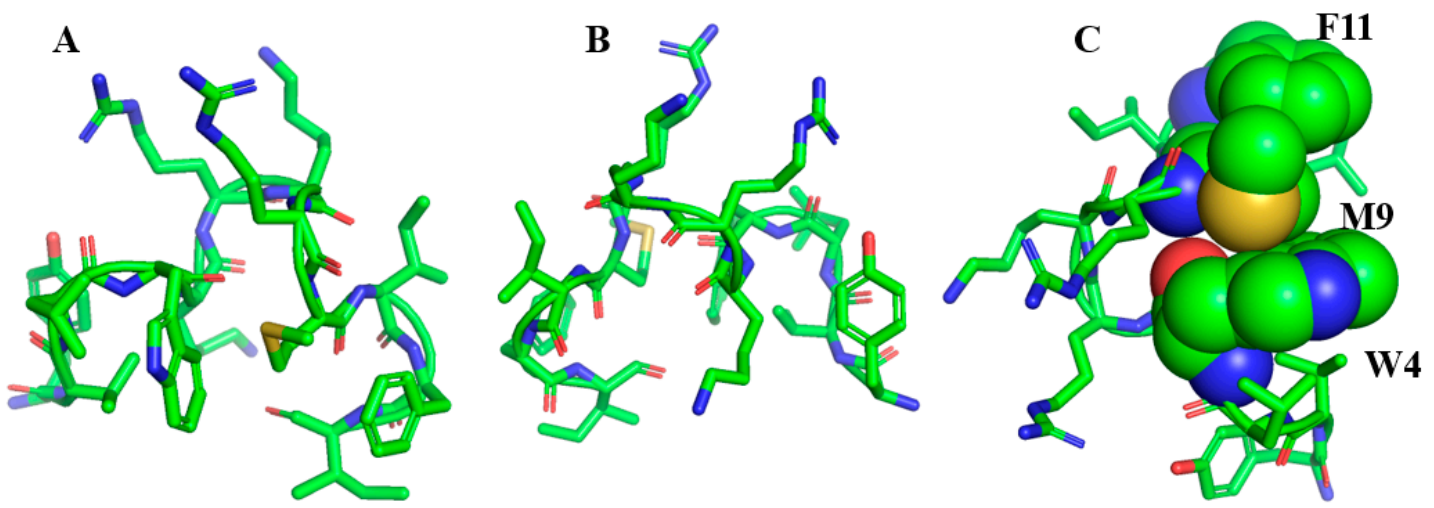

Figure 3. Structure of YW12 in LPS (pdb accession code: 2O0S): the $\beta$-boomerang shape inspired the design of the other peptides listed in Table 3. Sidechain dispositions of the $\beta$-boomerang structure are shown in two different orientations $(\mathbf{A}, \mathbf{B})$. The designed peptide assumed an amphipathic structure, with the central cationic residues $\mathrm{K}^{5} \mathrm{RKR}^{8}$ exposed to the outer periphery, whereas the $\mathrm{N}$ - and C-termini aromatic and non-polar residues sustained inward packing interactions. (C) Sidechains of residues W4, M9, and F11 of YW12 are in close packing interactions that are found to be critical for the activity.

Based on the structure of YW12 (Figure 3), second generation of $\beta$-boomerang peptides were designed in order to enhance antimicrobial and antiendotoxic activity. Given that Trp4 and Met9 are essential for the stabilization of the $\beta$-boomerang fold [115], Met9 was substituted to aromatic amino acids, Trp, Phe, and Tyr, in order to enhance packing interactions by aromatic/aromatic ring stacking (Figure 3c). The analog peptides listed in Table 3 were examined for in vitro antiendotoxic and antibacterial activity. YI12WY peptide demonstrated bactericidal activity against Gram negative and Gram positive strains. YI12FF peptide did not display high antiendotoxic and antibacterial activity. Additionally, antiendotoxic and antibacterial activity of either YI12LL (Leu4/Leu9) and YI12AA (Ala4/Ala9) peptides could not be detected. Atomic-resolution structures of the active analogs YI12WW, YI12WF, YI12WY and the inactive analog YI12AA were determined by NMR in LPS micelles. The long range packing between residue Trp4 and the aromatic residue, Phe/Tyr/Trp, at the ninth position acted as an 'aromatic lock', which is critical for the activity and $\beta$-boomerang amphipathic structure of the peptides. The inactive analog also folded into a compact amphipathic structure, but it was rather open at the $4 / 9$ end due to lack of the packing. The hexapeptide WKRKRF aromatic/cationic motif that potentially stabilizes the $\beta$-boomerang structure adopted a folded structure in LPS micelles, with mutual packing between Trp/Phe residues. This peptide sequence is the shortest segment known to bind LPS and was consequently termed as the 'Structured LPS Binding Motif' (see Section 2). The antiendotoxic and antibacterial activity of the $\beta$-boomerang peptides correlated well with the folded structure in LPS micelles. The active $\beta$-boomerang peptides were inserted into the micelles and disrupted higher order structural organization. As per the design, the four cationic residues at the centre of the $\beta$-boomerang appear to form ionic interactions with the phosphate groups of LPS and the hydrophobic residues at the $\mathrm{N}$ - and C-termini likely to destabilize the interchain packing of the acyl chains of LPS molecules.

$\mathrm{N}$-terminal acylation and disulfide bonds can improve the potency and endotoxin neutralization activity of AMPs. The $\beta$-boomerang peptide YI12WF was further engineered to yield disulfide bonded lipopeptides for enhancing antibacterial and antiendotoxic activity. The analogs of YI12WF were designed by changing the primary structure slightly to yield YI13C (with a Cys residue at 11th position for dimerization through disulfide bond formation) and attaching either C4 (C4-YI13C) or C8 acylation (C8-YI13C) at the N-terminus. An extra Lys residue was incorporated to increase the solubility of the designed analogs [146]. In bacterial growth inhibition assays, C8-YI13C demonstrated lower MIC values against Gram negative and Gram positive bacteria as compared to C4-YI13C and YI13C. The disulfide bonded YI13C and both disulfide bonded lipopeptides were active in neutralizing endotoxin [146]. All three analogs were able to neutralize over $80 \%$ of endotoxin at the highest tested 
dose of $1 \mathrm{EU} / \mathrm{mL}$ at a concentration of $10 \mu \mathrm{M}$. Lipopeptides, C4-YI13C and C8-YI13C, displayed endotoxin neutralization at even lower concentration ranges. To examine the role of the two aromatic residues in activity, residues Trp4 and Phe10 in the potent peptide C8-YI13C were substituted with Ala, resulting in peptide C8-YI13CAA. This Ala analog was devoid of antibacterial and antiendotoxic activity. The disulfide bonded lipopeptides bind to LPS at appreciably higher affinity when compared to the parent YI12WF peptide. Based on ITC experiments, $K_{d}$ was determined to be $0.23 \mu \mathrm{M}$ and $0.45 \mu \mathrm{M}$ for YI13C and C4-YI13C, respectively, whereas the parent peptide YI12WF binds to LPS with an estimated $\mathrm{K}_{\mathrm{d}}$ of $4.5 \mu \mathrm{M}$. As a mode of antibacterial activity, the designed analogs neutralized the surface charge of bacteria and efficiently permeabilized the outer and inner membranes of bacterial cells. The lipopeptides were largely non-hemolytic and interacted with negatively charged lipids in model membranes, akin to the parent $\beta$-boomerang peptide [146]. Moreover, the binding of the lipopeptides and YI13C resulted in the fragmentation of LPS micelles into smaller sized aggregates, a phenomenon that has been correlated with antiendotoxin activity of LPS-interacting proteins and peptides. The atomic-resolution structure of C4-YI13C could be determined in free solution by NMR while using 207 NOE distant constrains. This is in sharp contrast to the parent peptide YI12WF and other $\beta$-boomerang peptides, which adopt random conformations in free solution. The 3-D structure clearly established the amphipathic $\beta$-boomerang structure of the two subunits of the disulfide bonded C4-YI13C peptide. The stabilization of the $\beta$-boomerang structure either by the disulfide bonded C4-YI13C in free solution or for the parent peptides in LPS micelles established a clear intrinsic tendency of the designed sequences to adopt such conformations. A third generation of $\beta$-boomerang peptides are currently in development. These peptides are cyclized at the $\mathrm{N}$ - and C-termini and they show even more potent antibacterial activity, including against drug resistant bacteria in in vitro and in vivo murine models. Wound healing activity was also observed for some of these short cyclized peptides (unpublished results).

\section{Mining the Human Proteome for Novel AMPs}

The human proteome could serve as a platform for the discovery of new AMPs, since such AMPs are likely to be non-toxic and non-immunogenic to humans. The human proteome contains bonafide host defence peptides and proteins, which protect against disease. Human AMPs, such as LL37, various defensins ( $\alpha$ and $\beta$ ), histatins, and dermcidin, are expressed in skin, eyes, sweat, lungs, intestine lining, and the bladder [147-149]. These AMPs can directly kill pathogens or have immunomodulatory activity. Together with a number of proteins, such as lysozyme, different types of RNAse, chemokines, and psoriasin, AMPs are an integral part of human innate immunity. Aside from the bonafide AMPs and antimicrobial proteins, peptide fragments of native proteins can be active against invading pathogens [150-152]. These antimicrobial peptide fragments are usually hidden within the folded structure of proteins and they can only be released upon proteolytic digestion. For example, the antimicrobial fragments of blood coagulation protein thrombin were identified and characterized in terms of function and mode of action [152]. Thrombin derived peptide fragments are effective against a broad spectrum of bacteria in vitro and potentially also in in vivo wounds [153]. Thrombin peptides are active in modulating inflammation and are able to neutralize endotoxin, which plays an important role in sepsis [154]. In addition, several AMPs were discovered from DNA binding protein histones (H1, H2A, H2B, H3, H4, and H5) [155-157]. Histone-derived AMPs are rich in basic amino acids and adopt amphipathic, helical structures akin to many naturally occurring AMPs. Buforins, a group of potent amphibian AMPs, are postulated to be generated through pepsin-mediated proteolysis of histone $2 \mathrm{~A}$ in the cytoplasm of gastric gland cells [31,158]. As a mode of bacterial cell killing, buforins bind to DNA, whereas other histone derived AMPs are thought to be membrane active [30,159]. Fragments of large antimicrobial proteins, such as lysozyme and RNases have been reported to exert bacterial growth inhibition. Several lysozyme derived peptide fragments, including a helix-loop-helix peptide, were characterized for antibacterial activity and membrane interactions $[160,161]$. Antibacterial peptides can be obtained from bacterial cell agglutinating eosinophil cationic protein (RNase 3) and potent analogs 
were further designed based on the structures [162,163]. An AMP termed lactoferricin derived from the $\mathrm{N}$-terminal of iron binding protein lactoferrin and its shorter analogs were extensively characterized for antimicrobial activity and mechanism [164-170]. More recent studies have identified several fragments of ApoE protein with broad spectrum antimicrobial activity. A cryptic fragment of ApoE, residues 133-150 has been discovered using a novel bioinformatics method and was found to exert broad spectrum antibacterial activity, immunomodulation, and was less toxic to human cells [171]. Table 4 shows amino acid sequences of representative AMPs derived as fragments of proteins.

Table 4. Fragments of Intra-cellular Proteins as Potent AMPs.

\begin{tabular}{ccc}
\hline Name & Sequence & Net Charge \\
\hline TCP (C-terminal of thrombin) & GKYGFYTHVFRLKKWIQKVIDQFGE & +5 \\
Buforin II & TRSSRAGLQFPVGRVHRLLRK & +8 \\
Human lysozyme & DNIADAVACAKRVVRDPQGIRAWVAWRNR & +4 \\
Lactoferricin & KCFQWQRNMRKVRGPPVSCIKRDS & +6 \\
ApoE & LRVRLASHLRKLRKRLLR & +10 \\
Prodomain of Furin (YR26) & YYHFWHRGVTKRSLSPHRPRHSRLQR & +12 \\
\hline
\end{tabular}

Protein zymogens often undergo proteolytic digestion during activation, releasing inhibitory prodomains into circulation. Isolated prodomains are bestowed with physiological functions and stability. They may also be potentially involved in host defence activity. Based on this premise, antimicrobial peptides were recently discovered from the prodomain of human furin, a serine protease. Proprotein Convertases (PCs) are a family of Ser proteases that are responsible for processing of numerous precursor proteins at the consensus cleavage sites [172,173]. Furin, which belongs to the PC family, is known to be widely expressed in various cells and functions in the constitutive secretory pathway [172]. Apart from endogenous processing of precursor proteins, several bacterial and viral proteins are processed and activated by furin. The 81-amino acid long prodomain of human furin undergoes auto-catalytic cleavage during protease activation. The prodomain of furin is highly cationic ( $\mathrm{pI} \sim 12.2$ ) and also rich in aromatic/hydrophobic residues. NMR structural studies of the prodomain revealed a compact molten globule state under physiological solution conditions and well-folded stable helical conformations in the membrane mimic trifluoroethanol $[174,175]$. No antimicrobial activity could be detected for full-length furin despite the fact that the physicochemical properties and helical secondary structure of the prodomain are commonly observed in a large proportion of AMPs. This was likely due to the fact that the potential antibacterial region(s) of the prodomain may be buried inside the core of the structure and are unable to exert cell killing activity. Consequently, a number of overlapping peptide fragments i.e., residues V67-R81, residues Q62-R81, residues R57-R81, residues S52-R81, and residues T47-R81, of increasing length were tested for antimicrobial activity from the cationic C-terminus of the prodomain [176]. However, none of the peptide fragments displayed detectable growth inhibitory activity against a panel of Gram negative and Gram positive bacteria. Two overlapping peptide fragments from the N-terminus of the prodomain, namely residues Q1-F35 (or QF35) and residues R24-V46 (or RV23) were also devoid of antibacterial activity, except against a strain of E. coli, where MICs of $20 \mu \mathrm{M}$ and $4 \mu \mathrm{M}$ for QF35 and RV23, respectively, were found. Interestingly, a central 26-residue peptide fragment or YR26 (Table 4) was highly active in inhibiting the growth of Gram negative and Gram positive bacteria, with MICs in the range of 2 to $4 \mu \mathrm{M}$. YR26 peptide was also able to kill drug resistant S. aureus and S. epidermis strains at low MIC values [176]. The antibacterial activity of several truncated variants, obtained by removing amino acids from the C-terminus of YR26, were further examined for the identification of potentially active shorter analogs. Antibacterial activity was largely retained for peptide fragments YR23 and YR20 (Figure 4). However, further truncations of residues resulted in significantly reduced bacterial cell killing, with the exception of the much shorter fragment YR12, which showed killing of most of the tested bacterial strains, with MICs somewhat lower than the other longer variants. YR12 may be further engineered to develop 
potent short AMPs. It is important to note that all tested peptides had amidated C-termini. All three active peptides, YR26, YR23, and YR20, are non-hemolytic and non-toxic to fibroblast cells. YR23 was further investigated for anti-inflammatory activity demonstrating inhibition of secretion of TNF- $\alpha$ and IL- $\beta$ from LPS treated macrophage cells. Bacterial cell killing activity of the prodomain AMPs appears to occur via pore formation in membranes. Mechanistic investigations with live bacterial cells, LPS, and model liposomes revealed that the antibacterial peptides of the prodomain (a) disrupted the outer membrane-LPS permeability barrier and neutralized surface charge; (b) inserted into LPS micelles and destabilized the micellar structure; and, (c) interacted specifically with negatively charged lipids and caused the release of entrapped dyes from negatively charged POPC:POPG (3:1) liposomes. Interestingly, the binding of the prodomain peptides resulted fusion of liposomes (Figure 4).

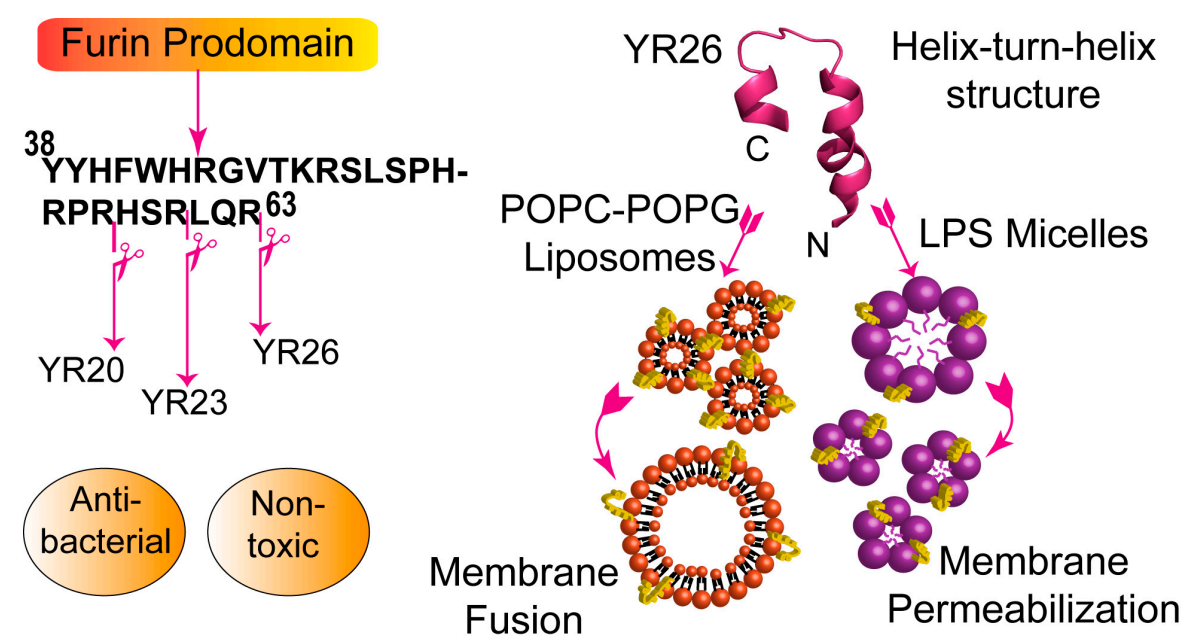

Figure 4. Truncation of furin prodomain to yield antimicrobial YR26, YR23, and YR20 (left). Structure and interaction of YR26 with model membranes (right). YR26 peptide assumed helix-turn-helix structure in SDS micelle and caused liposome fusion and LPS micelle dissociation. The figure was adapted from reference 176 . The pdb accession code of YR26 is 6A8Y.

The atomic resolution structure and backbone dynamics of YR26 peptide have been characterized while using standard methods and ${ }^{15} \mathrm{~N}$ relaxation experiments in negatively charged SDS micelles. YR26 adopted a helix-turn-helix structure, whereby a long N-terminal helix and a short C-terminal helix are connected by a tight turn (Figure 4). The helix-turn-helix structure of YR26 is rather non-amphipathic and it does not contain a clear disposition of distinct faces of cationic and hydrophobic residues. The striking feature of the helix-turn-helix structure is the presence of aromatic clusters at the N-terminal helix with a limited cationic patch, whereas the C-terminal helix accounted for most of the cationic surface. Based on the activity and a comparison of the structures of active and inactive truncated analogs, the membrane permeabilization, and bacterial cell killing afforded by YR26 peptide might be occurring due to cationic patches and aromatic cluster residues of the helix-turn-helix structure (Figure 4).

\section{Conclusions}

Arguably, at present, AMPs are vital candidates for fight against MDR and XDR bacteria. However, rational design, engineering and chemical modifications are necessary for the conversion of AMPs templates into in vivo active stable antibiotics. In this review, we have discussed the short helical AMPs temporins and aurein of frog skin, as well as de novo designed $\beta$-boomerang AMPs. Many analogs of temporins and aurein displayed improved antibacterial potency and higher therapeutic index. In addition, we highlight the discovery of novel AMPs that are derived from fragments of human proteins. The on-going efforts across the globe involving basic research and clinical trials of AMPs may deliver much needed next generation antibiotics. 
Author Contributions: Both S.B. and S.K.S. wrote and edited the manuscript. All authors have read and agreed to the published version of the manuscript.

Funding: S.B. acknowledges funding from Biomedical Research Council (BMRC), Singapore and Ministry of Education (MOE), Singapore. S.K.S. thanks the Natural Sciences and Engineering Research Council of Canada for funding.

Acknowledgments: The authors thank the many students who have contributed to the designed AMPs described herein.

Conflicts of Interest: The authors declare no conflict of interest.

\section{References}

1. Hancock, R.E.W.; Sahl, H.-G. Antimicrobial and host-defense peptides as new anti-infective therapeutic strategies. Nat. Biotechnol. 2006, 24, 1551-1557. [CrossRef]

2. Haney, E.F.; Hancock, R.E.W. Peptide design for antimicrobial and immunomodulatory applications. Biopolymers 2013, 100, 572-583. [CrossRef]

3. Haney, E.F.; Straus, S.K.; Hancock, R.E.W. Reassessing the Host Defense Peptide Landscape. Front. Chem. 2019, 7, 43. [CrossRef]

4. Kumar, P.; Kizhakkedathu, J.N.; Straus, S.K. Antimicrobial peptides: Diversity, mechanism of action and strategies to improve the activity and biocompatibility in vivo. Biomolecules 2018, 8, 4. [CrossRef]

5. Dale, B.A.; Tao, R.; Kimball, J.R.; Jurevic, R.J. Oral antimicrobial peptides and biological control of caries. BMC Oral Health 2006, 6 (Suppl. S1), S13. [CrossRef] [PubMed]

6. Davidopoulou, S.; Diza, E.; Menexes, G.; Kalfas, S. Salivary concentration of the antimicrobial peptide LL-37 in children. Arch. Oral Biol. 2012, 57, 865-869. [CrossRef] [PubMed]

7. Pütsep, K.; Carlsson, G.; Boman, H.G.; Andersson, M. Deficiency of antibacterial peptides in patients with morbus Kostmann: An observation study. Lancet 2002, 360, 1144-1149. [CrossRef]

8. Bowdish, D.M.E.; Davidson, D.J.; Hancock, R.E.W. A re-evaluation of the role of host defence peptides in mammalian immunity. Curr. Protein Pept. Sci. 2005, 6, 35-51. [CrossRef]

9. Nijnik, A.; Hancock, R. Host defence peptides: Antimicrobial and immunomodulatory activity and potential applications for tackling antibiotic-resistant infections. Emerg. Health Threats J. 2009, 2, e1. [CrossRef] [PubMed]

10. Felício, M.R.; Silva, O.N.; Gonçalves, S.; Santos, N.C.; Franco, O.L. Peptides with Dual Antimicrobial and Anticancer Activities. Front. Chem. 2017, 5, 5. [CrossRef]

11. Hoskin, D.W.; Ramamoorthy, A. Studies on anticancer activities of antimicrobial peptides. Biochim. Biophys. Acta 2008, 1778, 357-375. [CrossRef] [PubMed]

12. Chernysh, S.; Kim, S.I.; Bekker, G.; Pleskach, V.A.; Filatova, N.A.; Anikin, V.B.; Platonov, V.G.; Bulet, P. Antiviral and antitumor peptides from insects. Proc. Natl. Acad. Sci. USA 2002, 99, 12628-12632. [CrossRef] [PubMed]

13. Pletzer, D.; Hancock, R.E.W. Antibiofilm peptides: Potential as broadspectrum agents. J. Bacteriol. 2016, 198, 2572-2578. [CrossRef] [PubMed]

14. Yasir, M.; Willcox, M.D.P.; Dutta, D. Action of antimicrobial peptides against bacterial biofilms. Materials 2018, 11, 2468. [CrossRef] [PubMed]

15. Haney, E.F.; Brito-Sánchez, Y.; Trimble, M.J.; Mansour, S.C.; Cherkasov, A.; Hancock, R.E.W. Computer-aided Discovery of Peptides that Specifically Attack Bacterial Biofilms. Sci. Rep. 2018, 8, 1871. [CrossRef]

16. Pletzer, D.; Mansour, S.C.; Hancock, R.E.W. Synergy between conventional antibiotics and anti-biofilm peptides in a murine, sub-cutaneous abscess model caused by recalcitrant ESKAPE pathogens. PLoS Pathog. 2018, 14, e1007084. [CrossRef]

17. Uhlig, T.; Kyprianou, T.; Martinelli, F.G.; Oppici, C.A.; Heiligers, D.; Hills, D.; Calvo, X.R.; Verhaert, P. The emergence of peptides in the pharmaceutical business: From exploration to exploitation. EuPA Open Proteom. 2014. [CrossRef]

18. Kosikowska, P.; Lesner, A. Antimicrobial peptides (AMPs) as drug candidates: A patent review (2003-2015). Expert Opin. Ther. Pat. 2016, 26, 689-702. [CrossRef]

19. WHO Antimicrobial resistance. Bull. World Health Organ. 2014, 61, 383-394. [CrossRef]

20. CDC. Antibiotic Resistance Threats in the United States, 2019; U.S. Department of Health and Human Services, CDC: Atlanta, GA, USA, 2019. 
21. Abdelraouf, K.; Braggs, K.H.; Yin, T.; Truong, L.D.; Hu, M.; Tam, V.H. Characterization of polymyxin B-induced nephrotoxicity: Implications for dosing regimen design. Antimicrob. Agents Chemother. 2012, 56, 4625-4629. [CrossRef]

22. Dubashynskaya, N.V.; Skorik, Y.A. Polymyxin delivery systems: Recent advances and challenges. Pharmaceuticals 2020, 13, 83. [CrossRef] [PubMed]

23. Hashemi, M.M.; Rovig, J.; Weber, S.; Hilton, B.; Forouzan, M.M.; Savage, B. Susceptibility of Colistin-Resistant, Gram-Negative Bacteria to Antimicrobial Peptides and Ceragenins. Antimicrob. Agents Chemother. 2017, 61, 1-6. [CrossRef] [PubMed]

24. Lin, J.; Zhou, D.; Steitz, T.A.; Polikanov, Y.S.; Gagnon, M.G. Ribosome-Targeting Antibiotics: Modes of Action, Mechanisms of Resistance, and Implications for Drug Design. Annu. Rev. Biochem. 2018, 87, 451-478. [CrossRef] [PubMed]

25. Butler, M.S.; Paterson, D.L. Antibiotics in the clinical pipeline in October 2019. J. Antibiot. (Tokyo) 2020, 73, 329. [CrossRef] [PubMed]

26. Zasloff, M. Antimicrobial peptides of multicellular organisms. Nature 2002, 415, 389-395. [CrossRef]

27. Zasloff, M. Mysteries that still remain. Biochim. Biophys. Acta Biomembr. 2009, 1788, 1693-1694. [CrossRef]

28. Lázár, V.; Martins, A.; Spohn, R.; Daruka, L.; Grézal, G. Antibiotic-resistant bacteria show widespread collateral sensitivity to antimicrobial peptides. Nat. Microbiol. 2018, 3, 718-731. [CrossRef]

29. Raheem, N.; Straus, S.K. Mechanisms of Action for Antimicrobial Peptides with Antibacterial and Antibiofilm Functions. Front. Microbiol. 2019, 10, 1-14. [CrossRef]

30. Park, C.B.; Kim, H.S.; Kim, S.C. Mechanism of action of the antimicrobial peptide buforin II: Buforin II kills microorganisms by penetrating the cell membrane and inhibiting cellular functions. Biochem. Biophys. Res. Commun. 1998, 244, 253-257. [CrossRef]

31. Kobayashi, S.; Chikushi, A.; Tougu, S.; Imura, Y.; Nishida, M.; Yano, Y.; Matsuzaki, K. Membrane Translocation Mechanism of the Antimicrobial Peptide Buforin 2. Biochemistry 2004, 43, 15610-15616. [CrossRef]

32. Yeaman, M.R.; Yount, N.Y. Mechanisms of antimicrobial peptide action and resistance. Pharmacol. Rev. 2003, 55, 27-55. [CrossRef] [PubMed]

33. Papo, N.; Shai, Y. A molecular mechanism for lipopolysaccharide protection of Gram-negative bacteria from antimicrobial peptides. J. Biol. Chem. 2005, 280, 10378-10387. [CrossRef] [PubMed]

34. Snyder, S.; Kim, D.; McIntosh, T.J. Lipopolysaccharide bilayer structure: Effect of chemotype, core mutations, divalent cations, and temperature. Biochemistry 1999, 38, 10758-10767. [CrossRef] [PubMed]

35. Snyder, D.S.; McIntosh, T.J. The lipopolysaccharide barrier: Correlation of antibiotic susceptibility with antibiotic permeability and fluorescent probe binding kinetics. Biochemistry 2000, 39, 11777-11787. [CrossRef]

36. Nikaido, H.; Vaara, M. Molecular basis of bacterial outer membrane permeability. Microbiol. Rev. 1985, 49, 1-32. [CrossRef]

37. Nikaido, H. Prevention of drug access to bacterial targets: Permeability barriers and active efflux. Science 1994, 264, 382-388. [CrossRef]

38. Nikaido, H. Molecular Basis of Bacterial Outer Membrane Permeability Revisited. Microbiol. Mol. Biol. Rev. 2003, 67, 593-656. [CrossRef]

39. Bhattacharjya, S. De novo Designed Lipopolysaccharide Binding Peptides: Structure Based Development of Antiendotoxic and Antimicrobial Drugs. Curr. Med. Chem. 2010, 17, 3080-3093. [CrossRef]

40. Bhattacharjya, S.; Ramamoorthy, A. Multifunctional host defense peptides: Functional and mechanistic insights from NMR structures of potent antimicrobial peptides. FEBS J. 2009, 276, 6465-6473. [CrossRef]

41. Allende, D.; McIntosh, T.J. Lipopolysaccharides in bacterial membranes act like cholesterol in eukaryotic plasma membranes in providing protection against melittin-induced bilayer lysis. Biochemistry 2003, 42, 1101-1108. [CrossRef]

42. Cama, J.; Henney, A.M.; Winterhalter, M. Breaching the barrier: Quantifying antibiotic permeability across gram-negative bacterial membranes. J. Mol. Biol. 2019, 431, 3531-3546. [CrossRef] [PubMed]

43. Bhunia, A.; Ramamoorthy, A.; Bhattacharjya, S. Helical hairpin structure of a potent antimicrobial peptide MSI-594 in lipopolysaccharide micelles by NMR spectroscopy. Chem. A Eur. J. 2009, 15, 2036-2040. [CrossRef] [PubMed]

44. Bhunia, A.; Domadia, P.N.; Torres, J.; Hallock, K.J.; Ramamoorthy, A.; Bhattacharjya, S. NMR structure of pardaxin, a pore-forming antimicrobial peptide, in lipopolysaccharide micelles: Mechanism of outer membrane permeabilization. J. Biol. Chem. 2010, 285, 3883-3895. [CrossRef] [PubMed] 
45. Domadia, P.N.; Bhunia, A.; Ramamoorthy, A.; Bhattacharjya, S. Structure, interactions, and antibacterial activities of MSI-594 derived mutant peptide MSI-594F5A in lipopolysaccharide micelles: Role of the helical hairpin conformation in outer-membrane permeabilization. J. Am. Chem. Soc. 2010, 132, 18417-18428. [CrossRef] [PubMed]

46. Bhattacharjya, S. NMR Structures and Interactions of Antimicrobial Peptides with Lipopolysaccharide: Connecting Structures to Functions. Curr. Top. Med. Chem. 2015, 16, 4-15. [CrossRef] [PubMed]

47. Ilyas, H.; Kim, J.W.; Lee, D.K.; Malmsten, M.; Bhunia, A. Structural insights into the combinatorial effects of antimicrobial peptides reveal a role of aromatic-aromatic interactions in antibacterial synergism. J. Biol. Chem. 2019, 294, 14615-14633. [CrossRef]

48. Bello, G.; Bodin, A.; Lawrence, M.J.; Barlow, D.; Mason, A.J.; Barker, R.D.; Harvey, R.D. The influence of rough lipopolysaccharide structure on molecular interactions with mammalian antimicrobial peptides. Biochim. Biophys. Acta Biomembr. 2016, 1858, 197-209. [CrossRef]

49. Sinha, S.; Zheng, L.; Mu, Y.; Ng, W.J.; Bhattacharjya, S. Structure and interactions of a host defense antimicrobial peptide thanatin in lipopolysaccharide micelles reveal mechanism of bacterial cell agglutination. Sci. Rep. $2017,7$. [CrossRef]

50. Swarbrick, J.D.; Karas, J.A.; Li, J.; Velkov, T. Structure of micelle bound cationic peptides by NMR spectroscopy using a lanthanide shift reagent. Chem. Commun. 2020, 56, 2897-2900. [CrossRef]

51. Saravanan, R.; Holdbrook, D.A.; Petrlova, J.; Singh, S.; Berglund, N.A.; Choong, Y.K.; Kjellström, S.; Bond, P.J.; Malmsten, M.; Schmidtchen, A. Structural basis for endotoxin neutralisation and anti-inflammatory activity of thrombin-derived C-terminal peptides. Nat. Commun. 2018, 9. [CrossRef]

52. Kumar, A.; Mahajan, M.; Awasthi, B.; Tandon, A.; Harioudh, M.K.; Shree, S.; Singh, P.; Shukla, P.K.; Ramachandran, R.; Mitra, K.; et al. Piscidin-1-analogs with double L- and D-lysine residues exhibited different conformations in lipopolysaccharide but comparable anti-endotoxin activities. Sci. Rep. $2017,7$. [CrossRef] [PubMed]

53. Datta, A.; Ghosh, A.; Airoldi, C.; Sperandeo, P.; Mroue, K.H.; Jimenez-Barbero, J.; Kundu, P.; Ramamoorthy, A.; Bhunia, A. Antimicrobial peptides: Insights into membrane permeabilization, lipopolysaccharide fragmentation and application in plant disease control. Sci. Rep. 2015, 5. [CrossRef] [PubMed]

54. Wenzel, M.; Chiriac, A.I.; Otto, A.; Zweytick, D.; May, C.; Schumacher, C.; Gust, R.; Albada, H.B.; Penkova, M.; Krämer, U.; et al. Small cationic antimicrobial peptides delocalize peripheral membrane proteins. Proc. Natl. Acad. Sci. USA 2014, 111. [CrossRef] [PubMed]

55. Ishida, H.; Nguyen, L.T.; Gopal, R.; Aizawa, T.; Vogel, H.J. Overexpression of Antimicrobial, Anticancer, and Transmembrane Peptides in Escherichia coli through a Calmodulin-Peptide Fusion System. J. Am. Chem. Soc. 2016, 138, 11318-11326. [CrossRef] [PubMed]

56. Abdel Monaim, S.A.H.; Somboro, A.M.; El-Faham, A.; de la Torre, B.G.; Albericio, F. Bacteria Hunt Bacteria through an Intriguing Cyclic Peptide. ChemMedChem 2019, 14, 24-51. [CrossRef]

57. Wang, G. Post-Translational Modifications of Natural Antimicrobial Peptides and Strategies for Peptide Engineering. Curr. Biotechnol. 2012, 1, 72-79. [CrossRef]

58. Ting, D.S.J.; Beuerman, R.W.; Dua, H.S.; Lakshminarayanan, R.; Mohammed, I. Strategies in Translating the Therapeutic Potentials of Host Defense Peptides. Front. Immunol. 2020, 11, 983. [CrossRef]

59. Mourtada, R.; Herce, H.D.; Yin, D.J.; Moroco, J.A.; Wales, T.E.; Engen, J.R.; Walensky, L.D. Design of stapled antimicrobial peptides that are stable, nontoxic and kill antibiotic-resistant bacteria in mice. Nat. Biotechnol. 2019, 37, 1186-1197. [CrossRef]

60. Kumar, P.; Pletzer, D.; Haney, E.F.; Rahanjam, N.; Cheng, J.T.J.; Yue, M.; Aljehani, W.; Hancock, R.E.W.; Kizhakkedathu, J.N.; Straus, S.K. Aurein-Derived Antimicrobial Peptides Formulated with Pegylated Phospholipid Micelles to Target Methicillin-Resistant Staphylococcus aureus Skin Infections. ACS Infect. Dis. 2019, 5, 443-453. [CrossRef]

61. Wani, N.A.; Singh, G.; Shankar, S.; Sharma, A.; Katoch, M.; Rai, R. Short hybrid peptides incorporating $\beta$ and $\gamma$-amino acids as antimicrobial agents. Peptides 2017, 97, 46-53. [CrossRef]

62. Hicks, R.P.; Abercrombie, J.J.; Wong, R.K.; Leung, K.P. Antimicrobial peptides containing unnatural amino acid exhibit potent bactericidal activity against ESKAPE pathogens. Bioorg. Med. Chem. 2013, 21, 205-214. [CrossRef] [PubMed]

63. Qvit, N.; Rubin, S.J.S.; Urban, T.J.; Mochly-Rosen, D.; Gross, E.R. Peptidomimetic therapeutics: Scientific approaches and opportunities. Drug Discov. Today 2017, 22, 454-462. [CrossRef] [PubMed] 
64. Drayton, M.; Kizhakkedathu, J.N.; Straus, S.K. Towards Robust Delivery of Antimicrobial Peptides to Combat Bacterial Resistance. Molecules 2020, 25, 3048. [CrossRef] [PubMed]

65. Mangoni, M.L.; Papo, N.; Saugar, J.M.; Barra, D.; Shai, Y.; Simmaco, M.; Rivas, L. Effect of natural L- to D-amino acid conversion on the organization, membrane binding, and biological function of the antimicrobial peptides bombinins H. Biochemistry 2006, 45, 4266-4276. [CrossRef]

66. Saravanan, R.; Bhunia, A.; Bhattacharjya, S. Micelle-bound structures and dynamics of the hinge deleted analog of melittin and its diastereomer: Implications in cell selective lysis by d-amino acid containing antimicrobial peptides. Biochim. Biophys. Acta Biomembr. 2010, 1798, 128-139. [CrossRef]

67. Oren, Z.; Shai, Y. Selective lysis of bacteria but not mammalian cells by diastereomers of melittin: Structure-function study. Biochemistry 1997, 36, 1826-1835. [CrossRef]

68. Tripathi, A.K.; Kumari, T.; Harioudh, M.K.; Yadav, P.K.; Kathuria, M.; Shukla, P.K.; Mitra, K.; Ghosh, J.K. Identification of GXXXXG motif in Chrysophsin-1 and its implication in the design of analogs with cell-selective antimicrobial and anti-endotoxin activities. Sci. Rep. 2017, 7. [CrossRef]

69. Kumar, A.; Kumar Tripathi, A.; Kathuria, M.; Shree, S.; Kumar Tripathi, J.; Purshottam, R.K.; Ramachandran, R.; Mitra, K.; Kanti Ghosh, J. Single amino acid substitutions at specific positions of the heptad repeat sequence of piscidin-1 yielded novel analogs that show low cytotoxicity and in vitro and in vivo antiendotoxin activity. Antimicrob. Agents Chemother. 2016, 60, 3687-3699. [CrossRef]

70. Saravanan, R.; Li, X.; Lim, K.; Mohanram, H.; Peng, L.; Mishra, B.; Basu, A.; Lee, J.M.; Bhattacharjya, S.; Leong, S.S.J. Design of short membrane selective antimicrobial peptides containing tryptophan and arginine residues for improved activity, salt-resistance, and biocompatibility. Biotechnol. Bioeng. 2014, 111, 37-49. [CrossRef]

71. Kumar, P.; Takayesu, A.; Abbasi, U.; Kalathottukaren, M.T.; Abbina, S.; Kizhakkedathu, J.N.; Straus, S.K. Antimicrobial Peptide-Polymer Conjugates with High Activity: Influence of Polymer Molecular Weight and Peptide Sequence on Antimicrobial Activity, Proteolysis, and Biocompatibility. ACS Appl. Mater. Interfaces 2017, 9. [CrossRef]

72. Kumar, P.; Shenoi, R.A.; Lai, B.F.L.; Nguyen, M.; Kizhakkedathu, J.N.; Straus, S.K. Conjugation of Aurein 2.2 to HPG Yields an Antimicrobial with Better Properties. Biomacromolecules 2015, 16. [CrossRef] [PubMed]

73. Ladram, A.; Nicolas, P. Antimicrobial peptides from frog skin: Biodiversity and therapeutic promises. Front. Biosci. Landmark 2016, 21, 1341-1371. [CrossRef]

74. Xu, X.; Lai, R. The chemistry and biological activities of peptides from amphibian skin secretions. Chem. Rev. 2015, 115, 1760-1846. [CrossRef] [PubMed]

75. Rinaldi, A.C. Antimicrobial peptides from amphibian skin: An expanding scenario: Commentary. Curr. Opin. Chem. Biol. 2002, 6, 799-804. [CrossRef]

76. Pukala, T.L.; Bowie, J.H.; Maselli, V.M.; Musgrave, I.F.; Tyler, M.J. Host-defence peptides from the glandular secretions of amphibians: Structure and activity. Nat. Prod. Rep. 2006, 23, 368-393. [CrossRef] [PubMed]

77. Wang, G.; Li, X.; Wang, Z. APD3: The antimicrobial peptide database as a tool for research and education. Nucleic Acids Res. 2016, 44, D1087-D1093. [CrossRef] [PubMed]

78. Mangoni, M.L.; Di Grazia, A.; Cappiello, F.; Casciaro, B.; Luca, V. Naturally Occurring Peptides from Rana temporaria: Antimicrobial Properties and More. Curr. Top. Med. Chem. 2015, 16, 54-64. [CrossRef] [PubMed]

79. Simmaco, M.; Mignogna, G.; Canofeni, S.; Miele, R.; Mangoni, M.L.; Barra, D. Temporins, antimicrobial peptides from the European red frog Rana temporaria. Eur. J. Biochem. 1996, 242, 788-792. [CrossRef]

80. Mangoni, M.L.; Shai, Y. Temporins and their synergism against Gram-negative bacteria and in lipopolysaccharide detoxification. Biochim. Biophys. Acta Biomembr. 2009, 1788, 1610-1619. [CrossRef]

81. Mangoni, M.L. Temporins, anti-infective peptides with expanding properties. Cell. Mol. Life Sci. 2006, 63, 1060-1069. [CrossRef]

82. Mahalka, A.K.; Kinnunen, P.K.J. Binding of amphipathic $\alpha$-helical antimicrobial peptides to lipid membranes: Lessons from temporins B and L. Biochim. Biophys. Acta Biomembr. 2009, 1788, 1600-1609. [CrossRef] [PubMed]

83. Zhao, H.; Rinaldi, A.C.; Di Giulio, A.; Simmaco, M.; Kinnunen, P.K.J. Interactions of the antimicrobial peptides temporins with model biomembranes. Comparison of temporins B and L. Biochemistry 2002, 41, 4425-4436. [CrossRef] [PubMed] 
84. Rinaldi, A.C.; Mangoni, M.L.; Rufo, A.; Luzi, C.; Barra, D.; Zhao, H.; Kinnunen, P.K.J.; Bozzi, A.; Di Giulio, A.; Simmaco, M. Temporin L: Antimicrobial, haemolytic and cytotoxic activities, and effects on membrane permeabilization in lipid vesicles. Biochem. J. 2002, 368, 91-100. [CrossRef] [PubMed]

85. Mangoni, M.L.; Papo, N.; Barra, D.; Simmaco, M.; Bozzi, A.; Di Giulio, A.; Rinaldi, A.C. Effects of the antimicrobial peptide temporin $\mathrm{L}$ on cell morphology, membrane permeability and viability of Escherichia coli. Biochem. J. 2004, 380, 859-865. [CrossRef]

86. Giacometti, A.; Cirioni, O.; Kamysz, W.; D’Amato, G.; Silvestri, C.; Del Prete, M.S.; Licci, A.; Łukasiak, J.; Scalise, G. In vitro activity and killing effect of temporin A on nosocomial isolates of Enterococcus faecalis and interactions with clinically used antibiotics. J. Antimicrob. Chemother. 2005, 55, 272-274. [CrossRef]

87. Giacometti, A.; Cirioni, O.; Ghiselli, R.; Mocchegiani, F.; Orlando, F.; Silvestri, C.; Bozzi, A.; Di Giulio, A.; Luzi, C.; Mangoni, M.L.; et al. Interaction of antimicrobial peptide temporin L with lipopolysaccharide in vitro and in experimental rat models of septic shock caused by gram-negative bacterial. Antimicrob. Agents Chemother. 2006, 50, 2478-2486. [CrossRef]

88. Carotenuto, A.; Malfi, S.; Saviello, M.R.; Campiglia, P.; Gomez-Monterrey, I.; Mangoni, M.L.; Gaddi, L.M.H.; Novellino, E.; Grieco, P. A different molecular mechanism underlying antimicrobial and hemolytic actions of temporins A and L. J. Med. Chem. 2008, 51, 2354-2362. [CrossRef]

89. Mangoni, M.L.; Carotenuto, A.; Auriemma, L.; Saviello, M.R.; Campiglia, P.; Gomez-Monterrey, I.; Malfi, S.; Marcellini, L.; Barra, D.; Novellino, E.; et al. Structure-activity relationship, conformational and biological studies of temporin 1 analogues. J. Med. Chem. 2011, 54, 1298-1307. [CrossRef]

90. Saviello, M.R.; Malfi, S.; Campiglia, P.; Cavalli, A.; Grieco, P.; Novellino, E.; Carotenuto, A. New insight into the mechanism of action of the temporin antimicrobial peptides. Biochemistry 2010, 49, 1477-1485. [CrossRef]

91. Srivastava, S.; Ghosh, J.K. Introduction of a lysine residue promotes aggregation of temporin L in lipopolysaccharides and augmentation of its antiendotoxin property. Antimicrob. Agents Chemother. 2013, 57, 2457-2466. [CrossRef]

92. Dong, W.; Zhu, X.; Zhou, X.; Yang, Y.; Yan, X.; Sun, L.; Shang, D. Potential role of a series of lysine-/leucine-rich antimicrobial peptide in inhibiting lipopolysaccharide-induced inflammation. Biochem. J. 2018, 475, 3687-3706. [CrossRef] [PubMed]

93. Crépin, A.; Jégou, J.F.; André, S.; Ecale, F.; Croitoru, A.; Cantereau, A.; Berjeaud, J.M.; Ladram, A.; Verdon, J. In vitro and intracellular activities of frog skin temporins against Legionella pneumophila and its eukaryotic hosts. Sci. Rep. 2020, 10. [CrossRef] [PubMed]

94. Chadbourne, F.L.; Raleigh, C.; Ali, H.Z.; Denny, P.W.; Cobb, S.L. Studies on the antileishmanial properties of the antimicrobial peptides temporin A, B and 1Sa. J. Pept. Sci. 2011, 17, 751-755. [CrossRef] [PubMed]

95. Mangoni, M.L.; Saugar, J.M.; Dellisanti, M.; Barra, D.; Simmaco, M.; Rivas, L. Temporins, small antimicrobial peptides with leishmanicidal activity. J. Biol. Chem. 2005, 280, 984-990. [CrossRef]

96. Marcocci, M.E.; Amatore, D.; Villa, S.; Casciaro, B.; Aimola, P.; Franci, G.; Grieco, P.; Galdiero, M.; Palamara, A.T.; Mangoni, M.L.; et al. The amphibian antimicrobial peptide temporin $\mathrm{b}$ inhibits in vitro herpes simplex virus 1 infection. Antimicrob. Agents Chemother. 2018, 62. [CrossRef]

97. Simonetti, O.; Cirioni, O.; Goteri, G.; Ghiselli, R.; Kamysz, W.; Kamysz, E.; Silvestri, C.; Orlando, F.; Barucca, C.; Scalise, A.; et al. Temporin A is effective in MRSA-infected wounds through bactericidal activity and acceleration of wound repair in a murine model. Peptides 2008, 29, 520-528. [CrossRef]

98. Grazia, A.D.; Luca, V.; Segev-Zarko, L.A.T.; Shai, Y.; Mangoni, M.L. Temporins a and b stimulate migration of hacat keratinocytes and kill intracellular staphylococcus aureus. Antimicrob. Agents Chemother. 2014, 58, 2520-2527. [CrossRef]

99. Grieco, P.; Carotenuto, A.; Auriemma, L.; Saviello, M.R.; Campiglia, P.; Gomez-Monterrey, I.M.; Marcellini, L.; Luca, V.; Barra, D.; Novellino, E.; et al. The effect of d-amino acid substitution on the selectivity of temporin L towards target cells: Identification of a potent anti-Candida peptide. Biochim. Biophys. Acta Biomembr. 2013, 1828, 652-660. [CrossRef]

100. Diao, Y.; Han, W.; Zhao, H.; Zhu, S.; Liu, X.; Feng, X.; Gu, J.; Yao, C.; Liu, S.; Sun, C.; et al. Designed synthetic analogs of the $\alpha$-helical peptide temporin-La with improved antitumor efficacies via charge modification and incorporation of the integrin $\alpha \mathrm{v} \beta 3$ homing domain. J. Pept. Sci. 2012, 18, 476-486. [CrossRef]

101. Malgieri, G.; Avitabile, C.; Palmieri, M.; D’Andrea, L.D.; Isernia, C.; Romanelli, A.; Fattorusso, R. Structural basis of a temporin $1 \mathrm{~b}$ analogue antimicrobial activity against gram negative bacteria determined by $C D$ and NMR techniques in cellular environment. ACS Chem. Biol. 2015, 10, 965-969. [CrossRef] 
102. Mangoni, M.L.; Shai, Y. Short native antimicrobial peptides and engineered ultrashort lipopeptides: Similarities and differences in cell specificities and modes of action. Cell. Mol. Life Sci. 2011, 68, 2267-2280. [CrossRef] [PubMed]

103. Rosenfeld, Y.; Barra, D.; Simmaco, M.; Shai, Y.; Mangoni, M.L. A synergism between temporins toward Gram-negative bacteria overcomes resistance imposed by the lipopolysaccharide protective layer. J. Biol. Chem. 2006, 281, 28565-28574. [CrossRef] [PubMed]

104. Mangoni, M.L.; Epand, R.F.; Rosenfeld, Y.; Peleg, A.; Barra, D.; Epand, R.M.; Shai, Y. Lipopolysaccharide, a key molecule involved in the synergism between temporins in inhibiting bacterial growth and in endotoxin neutralization. J. Biol. Chem. 2008, 283, 22907-22917. [CrossRef] [PubMed]

105. Avitabile, C.; Netti, F.; Orefice, G.; Palmieri, M.; Nocerino, N.; Malgieri, G.; D'Andrea, L.D.; Capparelli, R.; Fattorusso, R.; Romanelli, A. Design, structural and functional characterization of a Temporin-1b analog active against Gram-negative bacteria. Biochim. Biophys. Acta Gen. Subj. 2013, 1830, 3767-3775. [CrossRef]

106. Saravanan, R.; Joshi, M.; Mohanram, H.; Bhunia, A.; Mangoni, M.L.; Bhattacharjya, S. NMR Structure of Temporin-1 Ta in Lipopolysaccharide Micelles: Mechanistic Insight into Inactivation by Outer Membrane. PLoS ONE 2013, 8. [CrossRef]

107. Bhunia, A.; Saravanan, R.; Mohanram, H.; Mangoni, M.L.; Bhattacharjya, S. NMR structures and interactions of temporin-1Tl and temporin-1Tb with lipopolysaccharide micelles: Mechanistic insights into outer membrane permeabilization and synergistic activity. J. Biol. Chem. 2011, 286, 24394-24406. [CrossRef]

108. Avitabile, C.; D'Andrea, L.D.; Saviano, M.; Olivieri, M.; Cimmino, A.; Romanelli, A. Binding studies of antimicrobial peptides to Escherichia coli cells. Biochem. Biophys. Res. Commun. 2016, 478, 149-153. [CrossRef]

109. Grassi, L.; Maisetta, G.; Maccari, G.; Esin, S.; Batoni, G. Analogs of the frog-skin antimicrobial peptide temporin $1 \mathrm{~Tb}$ exhibit a wider spectrum of activity and a stronger antibiofilm potential as compared to the parental peptide. Front. Chem. 2017, 5. [CrossRef]

110. Manzo, G.; Ferguson, P.M.; Gustilo, V.B.; Hind, C.K.; Clifford, M.; Bui, T.T.; Drake, A.F.; Atkinson, R.A.; Sutton, J.M.; Batoni, G.; et al. Minor sequence modifications in temporin B cause drastic changes in antibacterial potency and selectivity by fundamentally altering membrane activity. Sci. Rep. $2019,9$. [CrossRef]

111. Capparelli, R.; Romanelli, A.; Iannaccone, M.; Nocerino, N.; Ripa, R.; Pensato, S.; Pedone, C.; Iannelli, D. Synergistic antibacterial and anti-inflammatory activity of temporin A and modified temporin B in vivo. PLoS ONE 2009, 4. [CrossRef]

112. Grieco, P.; Luca, V.; Auriemma, L.; Carotenuto, A.; Saviello, M.R.; Campiglia, P.; Barra, D.; Novellino, E.; Mangoni, M.L. Alanine scanning analysis and structure-function relationships of the frog-skin antimicrobial peptide temporin-1Ta. J. Pept. Sci. 2011, 17, 358-365. [CrossRef] [PubMed]

113. Merlino, F.; Carotenuto, A.; Casciaro, B.; Martora, F.; Loffredo, M.R.; Di Grazia, A.; Yousif, A.M.; Brancaccio, D.; Palomba, L.; Novellino, E.; et al. Glycine-replaced derivatives of [Pro3,DLeu9]TL, a temporin L analogue: Evaluation of antimicrobial, cytotoxic and hemolytic activities. Eur. J. Med. Chem. 2017, 139, 750-761. [CrossRef] [PubMed]

114. Srivastava, S.; Kumar, A.; Tripathi, A.K.; Tandon, A.; Ghosh, J.K. Modulation of anti-endotoxin property of Temporin L by minor amino acid substitution in identified phenylalanine zipper sequence. Biochem. J. 2016, 473, 4045-4062. [CrossRef] [PubMed]

115. Bhunia, A.; Mohanram, H.; Domadia, P.N.; Torres, J.; Bhattacharjya, S. Designed $\beta$-boomerang antiendotoxic and antimicrobial peptides. Structures and activities in lipopolysaccharide. J. Biol. Chem. 2009, 284, 21991-22004. [CrossRef] [PubMed]

116. Mohanram, H.; Bhattacharjya, S. Resurrecting inactive antimicrobial peptides from the lipopolysaccharide trap. Antimicrob. Agents Chemother. 2014, 58, 1987-1996. [CrossRef]

117. Mohanram, H.; Bhattacharjya, S. 'Lollipop'-shaped helical structure of a hybrid antimicrobial peptide of temporin B-lipopolysaccharide binding motif and mapping cationic residues in antibacterial activity. Biochim. Biophys. Acta Gen. Subj. 2016, 1860, 1362-1372. [CrossRef]

118. Rozek, T.; Wegener, K.L.; Bowie, J.H.; Olver, I.N.; Carver, J.A.; Wallace, J.C.; Tyler, M.J. The antibiotic and anticancer active aurein peptides from the Australian Bell Frogs Litoria aurea and Litoria raniformis: The solution structure of aurein 1.2. Eur. J. Biochem. 2000, 267, 5330-5341. [CrossRef] 
119. Rozek, T.; Bowie, J.H.; Wallace, J.C.; Tyler, M.J. The antibiotic and anticancer active aurein peptides from the Australian Bell FrogsLitoria aurea andLitoria raniformis. Part 2. Sequence determination using electrospray mass spectrometry. Rapid Commun. Mass Spectrom. 2000, 14, 2002-2011. [CrossRef]

120. Cheng, J.T.J.; Hale, J.D.; Elliot, M.; Hancock, R.E.W.; Straus, S.K. Effect of membrane composition on antimicrobial peptides aurein 2.2 and 2.3 from australian southern bell frogs. Biophys. J. 2009, 96. [CrossRef]

121. Pan, Y.-L.; Cheng, J.T.-J.; Hale, J.; Pan, J.; Hancock, R.E.W.; Straus, S.K. Characterization of the structure and membrane interaction of the antimicrobial peptides aurein 2.2 and 2.3 from Australian southern bell frogs. Biophys. J. 2007, 92. [CrossRef]

122. Cheng, J.T.J.; Hale, J.D.; Elliott, M.; Hancock, R.E.W.; Straus, S.K. The importance of bacterial membrane composition in the structure and function of aurein 2.2 and selected variants. Biochim. Biophys. Acta Biomembr. 2011, 1808. [CrossRef] [PubMed]

123. Cheng, J.T.J.; Hale, J.D.; Kindrachuk, J.; Jessen, H.; Elliott, M.; Hancock, R.E.W.; Straus, S.K. Importance of residue 13 and the $\mathrm{C}$-terminus for the structure and activity of the antimicrobial peptide aurein 2.2. Biophys. J. 2010, 99. [CrossRef] [PubMed]

124. Manzo, G.; Ferguson, P.M.; Hind, C.K.; Clifford, M.; Gustilo, V.B.; Ali, H.; Bansal, S.S.; Bui, T.T.; Drake, A.F.; Atkinson, R.A.; et al. Temporin $\mathrm{L}$ and aurein 2.5 have identical conformations but subtly distinct membrane and antibacterial activities. Sci. Rep. 2019, 9. [CrossRef]

125. Fernandez, D.I.; Le Brun, A.P.; Whitwell, T.C.; Sani, M.A.; James, M.; Separovic, F. The antimicrobial peptide aurein 1.2 disrupts model membranes via the carpet mechanism. Phys. Chem. Chem. Phys. 2012, 14, 15739-15751. [CrossRef] [PubMed]

126. Fernandez, D.I.; Sani, M.A.; Miles, A.J.; Wallace, B.A.; Separovic, F. Membrane defects enhance the interaction of antimicrobial peptides, aurein 1.2 versus caerin 1.1. Biochim. Biophys. Acta Biomembr. 2013, 1828, 1863-1872. [CrossRef] [PubMed]

127. Wenzel, M.; Senges, C.H.R.; Zhang, J.; Suleman, S.; Nguyen, M.; Kumar, P.; Chiriac, A.I.; Stepanek, J.J.; Raatschen, N.; May, C.; et al. Antimicrobial peptides from the aurein family form ion-selective pores in Bacillus subtilis. ChemBioChem 2015, 16. [CrossRef]

128. Haney, E.F.; Nguyen, L.T.; Schibli, D.J.; Vogel, H.J. Design of a novel tryptophan-rich membrane-active antimicrobial peptide from the membrane-proximal region of the HIV glycoprotein, gp41. Beilstein J. Org. Chem. 2012, 8, 1172-1184. [CrossRef]

129. Chan, D.I.; Prenner, E.J.; Vogel, H.J. Tryptophan- and arginine-rich antimicrobial peptides: Structures and mechanisms of action. Biochim. Biophys. Acta Biomembr. 2006, 1758, 1184-1202. [CrossRef]

130. Frank, R. The SPOT-synthesis Technique. Synthethic Peptide Arrays on Membrane Support-Principles and Applications. J. Immunol. Methods 2002, 267, 13-26. [CrossRef]

131. Hilpert, K.; Winkler, D.F.H.; Hancock, R.E.W. Peptide arrays on cellulose support: SPOT synthesis, a time and cost efficient method for synthesis of large numbers of peptides in a parallel and addressable fashion. Nat. Protoc. 2007, 2, 1333-1349. [CrossRef]

132. Winkler, D.F.H.; Hilpert, K.; Brandt, O.; Hancock, R.E.W. Peptide Microarrays. Methods and Protocols; Cretich, M., Chiari, M., Eds.; Springer: Dordrecht, The Netherlands; Heidelberg, Germany; London, UK; New York, NY, USA, 2009; p. 570. [CrossRef]

133. Haney, E.F.; Mansour, S.C.; Hilchie, A.L.; de la Fuente-Núñez, C.; Hancock, R.E.W. High Throughput Screening Methods for Assessing Antibiofilm and Immunomodulatory Activities of Synthetic Peptides. Peptides 2015, 71, 276-285. [CrossRef] [PubMed]

134. Cherkasov, A.; Hilpert, K.; Jenssen, H.; Fjell, C.D.; Waldbrook, M.; Mullaly, S.C.; Volkmer, R.; Hancock, R.E.W. Use of Artificial Intelligence in the Design of Small Peptide Antibiotics Effective against a Broad Spectrum of Highly Antibiotic-Resistant Superbugs. ACS Chem. Biol. 2009, 4, 65-74. [CrossRef] [PubMed]

135. Winkler, D.F.H.; Hilpert, K.; Brandt, O.; Hancock, R.E.W. Synthesis of peptide arrays using SPOT-technology and the CelluSpots-method. Methods Mol. Biol. 2009, 570, 157-174. [CrossRef] [PubMed]

136. Raheem, N.; Kumar, P.; Lee, E.; Cheng, J.T.J.; Hancock, R.E.W.; Straus, S.K. Insights into the mechanism of action of two analogues of aurein 2.2. Biochim. Biophys. Acta Biomembr. 2020, 1862. [CrossRef] [PubMed]

137. Hsu, C.H.; Chen, C.; Jou, M.L.; Lee, A.Y.L.; Lin, Y.C.; Yu, Y.P.; Huang, W.T.; Wu, S.H. Structural and DNA-binding studies on the bovine antimicrobial peptide, indolicidin: Evidence for multiple conformations involved in binding to membranes and DNA. Nucleic Acids Res. 2005, 33, 4053-4064. [CrossRef] [PubMed] 
138. Marchand, C.; Krajewski, K.; Lee, H.-F.; Antony, S.; Johnson, A.A.; Amin, R.; Roller, P.; Kvaratskhelia, M.; Pommier, Y. Covalent binding of the natural antimicrobial peptide indolicidin to DNA abasic sites. Nucleic Acids Res. 2006, 34, 5157-5165. [CrossRef]

139. Overhage, J.; Campisano, A.; Bains, M.; Torfs, E.C.W.; Rehm, B.H.A.; Hancock, R.E.W. Human host defense peptide LL-37 prevents bacterial biofilm formation. Infect. Immun. 2008, 76, 4176-4182. [CrossRef]

140. Sugawara, M.; Resende, J.M.; Moraes, C.M.; Marquette, A.; Chich, J.-F.; Metz-Boutigue, M.-H.; Bechinger, B. Membrane structure and interactions of human catestatin by multidimensional solution and solid-state NMR spectroscopy. FASEB J. 2010, 24, 1737-1746. [CrossRef]

141. Khafagy, E.S.; Morishita, M.; Ida, N.; Nishio, R.; Isowa, K.; Takayama, K. Structural requirements of penetratin absorption enhancement efficiency for insulin delivery. J. Control Release 2010, 143, 302-310. [CrossRef]

142. Vogt, T.C.B.; Bechinger, B. The interactions of histidine-containing amphipathic helical peptide antibiotics with lipid bilayers. The effects of charges and pH. J. Biol. Chem. 1999, 274, 29115-29121. [CrossRef]

143. Kichler, A.; Leborgne, C.; März, J.; Danos, O.; Bechinger, B. Histidine-rich amphipathic peptide antibiotics promote efficient delivery of DNA into mammalian cells. Proc. Natl. Acad. Sci. USA 2003, 100, 1564-1568. [CrossRef] [PubMed]

144. Moulay, G.; Leborgne, C.; Mason, A.J.; Aisenbrey, C.; Kichler, A.; Bechinger, B. Histidine-rich designer peptides of the LAH4 family promote cell delivery of a multitude of cargo. J. Pept. Sci. 2017, 23, 320-328. [CrossRef] [PubMed]

145. Bhattacharjya, S.; Domadia, P.N.; Bhunia, A.; Malladi, S.; David, S.A. High-resolution solution structure of a designed peptide bound to lipopolysaccharide: Transferred nuclear overhauser effects, micelle selectivity, and anti-endotoxic activity. Biochemistry 2007, 46, 5864-5874. [CrossRef] [PubMed]

146. Mohanram, H.; Bhattacharjya, S. $\beta$-boomerang antimicrobial and antiendotoxic peptides: Lipidation and disulfide bond effects on activity and structure. Pharmaceuticals 2014, 7, 482-501. [CrossRef]

147. Mathew, B.; Nagaraj, R. Variations in the interaction of human defensins with Escherichia coli: Possible implications in bacterial killing. PLoS ONE 2017, 12. [CrossRef]

148. Wang, C.; Shen, M.; Gohain, N.; Tolbert, W.D.; Chen, F.; Zhang, N.; Yang, K.; Wang, A.; Su, Y.; Cheng, T.; et al. Design of a Potent Antibiotic Peptide Based on the Active Region of Human Defensin 5. J. Med. Chem. 2015, 58, 3083-3093. [CrossRef]

149. Du, H.; Puri, S.; McCall, A.; Norris, H.L.; Russo, T.; Edgerton, M. Human salivary protein histatin 5 has potent bactericidal activity against ESKAPE pathogens. Front. Cell. Infect. Microbiol. 2017, 7. [CrossRef]

150. Papareddy, P.; Mörgelin, M.; Walse, B.; Schmidtchen, A.; Malmsten, M. Antimicrobial activity of peptides derived from human B-amyloid precursor protein. J. Pept. Sci. 2012, 18, 183-191. [CrossRef]

151. Kasetty, G.; Papareddy, P.; Kalle, M.; Rydengrd, V.; Walse, B.; Svensson, B.; Mörgelin, M.; Malmsten, M.; Schmidtchen, A. The C-terminal sequence of several human serine proteases encodes host defense functions. J. Innate Immun. 2011, 3, 471-482. [CrossRef]

152. Papareddy, P.; Rydengård, V.; Pasupuleti, M.; Walse, B.; Mörgelin, M.; Chalupka, A.; Malmsten, M.; Schmidtchen, A. Proteolysis of human thrombin generates novel host defense peptides. PLoS Pathog. 2010, 6. [CrossRef]

153. Petrlova, J.; Hansen, F.C.; Van Der Plas, M.J.A.; Huber, R.G.; Mörgelin, M.; Malmsten, M.; Bond, P.J.; Schmidtchen, A. Aggregation of thrombin-derived C-terminal fragments as a previously undisclosed host defense mechanism. Proc. Natl. Acad. Sci. USA 2017, 114, E4213-E4222. [CrossRef] [PubMed]

154. Kasetty, G.; Papareddy, P.; Kalle, M.; Rydengård, V.; Mörgelin, M.; Albiger, B.; Malmsten, M.; Schmidtchen, A. Structure-activity studies and therapeutic potential of host defense peptides of human thrombin. Antimicrob. Agents Chemother. 2011, 55, 2880-2890. [CrossRef] [PubMed]

155. Park, C.B.; Kim, M.S.; Kim, S.C. A novel antimicrobial peptide from Bufo bufo gargarizans. Biochem. Biophys. Res. Commun. 1996, 218, 408-413. [CrossRef] [PubMed]

156. Kawasaki, H.; Iwamuro, S. Potential Roles of Histones in Host Defense as Antimicrobial Agents. Infect. Disord. Drug Targets 2012, 8, 195-205. [CrossRef] [PubMed]

157. Hoeksema, M.; Van Eijk, M.; Haagsman, H.P.; Hartshorn, K.L. Histones as mediators of host defense, inflammation and thrombosis. Future Microbiol. 2016, 11, 441-453. [CrossRef]

158. Cho, J.H.; Sung, B.H.; Kim, S.C. Buforins: Histone H2A-derived antimicrobial peptides from toad stomach. Biochim. Biophys. Acta Biomembr. 2009, 1788, 1564-1569. [CrossRef] 
159. Sim, S.; Wang, P.; Beyer, B.N.; Cutrona, K.J.; Radhakrishnan, M.L.; Elmore, D.E. Investigating the nucleic acid interactions of histone-derived antimicrobial peptides. FEBS Lett. 2017, 591, 706-717. [CrossRef]

160. Ibrahim, H.R.; Thomas, U.; Pellegrini, A. A Helix-Loop-Helix Peptide at the Upper Lip of the Active Site Cleft of Lysozyme Confers Potent Antimicrobial Activity with Membrane Permeabilization Action. J. Biol. Chem. 2001, 276, 43767-43774. [CrossRef]

161. Hunter, H.N.; Jing, W.; Schibli, D.J.; Trinh, T.; Park, I.Y.; Kim, S.C.; Vogel, H.J. The interactions of antimicrobial peptides derived from lysozyme with model membrane systems. Biochim. Biophys. Acta Biomembr. 2005, 1668, 175-189. [CrossRef]

162. Harder, J.; Schröder, J.M. RNase 7, a novel innate immune defense antimicrobial protein of healthy human skin. J. Biol. Chem. 2002, 277, 46779-46784. [CrossRef]

163. Pulido, D.; Moussaoui, M.; Andreu, D.; Nogués, M.V.; Torrent, M.; Boix, E. Antimicrobial action and cell agglutination by the eosinophil cationic protein are modulated by the cell wall lipopolysaccharide structure. Antimicrob. Agents Chemother. 2012, 56, 2378-2385. [CrossRef] [PubMed]

164. Svendsen, J.S.M.; Grant, T.M.; Rennison, D.; Brimble, M.A.; Svenson, J. Very Short and Stable Lactoferricin-Derived Antimicrobial Peptides: Design Principles and Potential Uses. Acc. Chem. Res. 2019, 52, 749-759. [CrossRef] [PubMed]

165. Hossain, F.; Moghal, M.M.R.; Islam, M.Z.; Moniruzzaman, M.; Yamazaki, M. Membrane potential is vital for rapid permeabilization of plasma membranes and lipid bilayers by the antimicrobial peptide lactoferricin $B$. J. Biol. Chem. 2019, 294, 10449-10462. [CrossRef] [PubMed]

166. Nguyen, L.T.; Chau, J.K.; Perry, N.A.; de Boer, L.; Zaat, S.A.J.; Vogel, H.J. Serum stabilities of short tryptophanand arginine-rich antimicrobial peptide analogs. PLOS ONE 2010, 5, e12684. [CrossRef] [PubMed]

167. Gifford, J.L.; Hunter, H.N.; Vogel, H.J. Lactoferricin: A lactoferrin-derived peptide with antimicrobial, antiviral, antitumor and immunological properties. Cell. Mol. Life Sci. 2005, 62, 2588-2598. [CrossRef] [PubMed]

168. Hunter, H.N.; Ross Demcoe, A.; Jenssen, H.; Gutteberg, T.J.; Vogel, H.J. Human lactoferricin is partially folded in aqueous solution and is better stabilized in a membrane mimetic solvent. Antimicrob. Agents Chemother. 2005, 49, 3387-3395. [CrossRef]

169. Haney, E.F.; Nazmi, K.; Bolscher, J.G.M.; Vogel, H.J. Structural and biophysical characterization of an antimicrobial peptide chimera comprised of lactoferricin and lactoferrampin. Biochim. Biophys. Acta 2012, 1818, 762-775. [CrossRef]

170. Arias, M.; Hilchie, A.L.; Haney, E.F.; Bolscher, J.G.M.; Hyndman, M.E.; Hancock, R.E.W.; Vogel, H.J. Anticancer activities of bovine and human lactoferricin-derived peptides. Biochem. Cell Biol. 2017, 95, 91-98. [CrossRef]

171. Pane, K.; Sgambati, V.; Zanfardino, A.; Smaldone, G.; Cafaro, V.; Angrisano, T.; Pedone, E.; Di Gaetano, S.; Capasso, D.; Haney, E.F.; et al. A new cryptic cationic antimicrobial peptide from human apolipoprotein E with antibacterial activity and immunomodulatory effects on human cells. FEBS J. 2016, 283, 2115-2131. [CrossRef]

172. Thomas, G. Furin at the cutting edge: From protein traffic to embryogenesis and disease. Nat. Rev. Mol. Cell Biol. 2002, 3, 753-766. [CrossRef]

173. Seidah, N.G.; Sadr, M.S.; Chrétien, M.; Mbikay, M. The multifaceted proprotein convertases: Their unique, redundant, complementary, and opposite functions. J. Biol. Chem. 2013, 288, 21473-21481. [CrossRef] [PubMed]

174. Bhattacharjya, S.; Xu, P.; Xiang, H.; Chrétien, M.; Seidah, N.G.; Ni, F. pH-induced conformational transitions of a molten-globule-like state of the inhibitory prodomain of furin: Implications for zymogen activation. Protein Sci. 2001, 10, 934-942. [CrossRef] [PubMed]

175. Bhattacharjya, S.; Xu, P.; Wang, P.; Osborne, M.J.; Ni, F. Conformational analyses of a partially-folded bioactive prodomain of human furin. Biopolymers 2007, 86, 329-344. [CrossRef] [PubMed]

176. Sinha, S.; Harioudh, M.K.; Dewangan, R.P.; Ng, W.J.; Ghosh, J.K.; Bhattacharjya, S. Cell-Selective Pore Forming Antimicrobial Peptides of the Prodomain of Human Furin: A Conserved Aromatic/Cationic Sequence Mapping, Membrane Disruption, and Atomic-Resolution Structure and Dynamics. ACS Omega 2018, 3, 14650-14664. [CrossRef]

(C) 2020 by the authors. Licensee MDPI, Basel, Switzerland. This article is an open access article distributed under the terms and conditions of the Creative Commons Attribution (CC BY) license (http://creativecommons.org/licenses/by/4.0/). 